\title{
Intertextualidade musical na música religiosa de Alberto Nepomuceno
}

\author{
Musical intertextuality in Alberto Nepomuceno's religious music
}

\author{
Thiago Plaça Teixeira \\ Unespar-EMBAP
}

\begin{abstract}
Resumo: O presente artigo tem por objeto principal a identificação de categorias de intertextualidade musical na música sacra e religiosa do compositor brasileiro Alberto Nepomuceno (1864-1920). Em primeiro lugar, apresenta-se uma proposta de classificação de tal repertório em três grupos: música sacra, oratório (sentido "lato") e música instrumental religiosa. Em segundo lugar, apresenta-se uma breve discussão sobre a teorização das categorias de intertextualidade musical. Em terceiro lugar, procura-se analisar as peças religiosas de Nepomuceno sob o viés de intertextualidade musical, resultando na identificação de citações de esquemas formais, de citação textuais e estilísticas em vários níveis estruturais, sobretudo em três obras: Cloches de Noël, Em Bethleem e Missa a duas vozes.
\end{abstract}

Palavras-chave: Alberto Nepomuceno; Música sacra e religiosa; Análise musical; Intertextualidade

\begin{abstract}
This article aims to identify categories of musical intertextuality in the sacred and religious music composed by Alberto Nepomuceno (1864-1920). Firstly, it presents a classification of the repertoire into three groups: sacred music, oratory (latu sensu) and religious instrumental music. Second, I briefly discuss the theories of musical intertextuality's categories. Third, I analyze Nepomuceno's religious pieces under musical intertextuality, it was identified quotes from formal schemes, textual and stylistic quotes in various structural levels, mainly in three works: Cloches de Noël, Em Bethleem and Mass for two voices.
\end{abstract}

Keywords: Alberto Nepomuceno; Sacred and religious music; Musical analysis; Intertextuality 


\section{Nepomuceno e a música religiosa}

Entre os muitos gêneros musicais aos quais o importante compositor brasileiro Alberto Nepomuceno (1864-1920) se dedicou está o da música sacra (música destinada à Liturgia católica) e também o da música puramente religiosa, sem função ritual. O contato de Nepomuceno com esse tipo de música se deu em cinco âmbitos distintos, mas diretamente interligados.

Primeiramente, na sua formação religiosa. Nascido a 6 de julho de 1864, recebeu o Batismo católico em 15 de janeiro de 1865 na Catedral de Fortaleza, igreja em que seu pai, Victor Augusto Nepomuceno, era violinista e organista (Kiefer 1976, p. 110). Por algumas das dedicatórias de suas composições depreende-se que procurou dar formação católica à família, tal como se vê no Álbum eucarístico, no qual duas peças são dedicadas à Primeira Comunhão de suas duas filhas (Nepomuceno 1926). Por ocasião de seu envolvimento com a regulamentação da música sacra no Rio de Janeiro, ele escreve certa vez ao crítico musical José Rodrigues Barbosa (1857-1939): “Desejando que vossa ideia ache no coração dos sacerdotes e artistas, como no dos crentes, o mesmo eco que encontrou no meu, ponho-me inteiramente à vossa disposição, e ao serviço dessa causa sublime o meu ideal de crente e de artista" (Jornal do Commercio, Rio de Janeiro, 09/10/1895). Além disso, atuou eventualmente como regente ou organista em cerimônicas religiosas (Cf. A União, Rio de Janeiro, 18/09/1905) e sabe-se também que morreu católico, tendo recebido os últimos Sacramentos (Cf. A União, Rio de Janeiro. 21/10/1920).

Em segundo lugar, na sua formação musical. Em 1889 matriculou-se no Liceo Musicale Santa Cecilia (atual Conservatorio di Musica Santa Cecilia) da "Accademia" de mesmo nome, em Roma. Deste período há uma carta do compositor a seu amigo Frederico Nascimento (1852-1924), na qual se verifica o contato acadêmico com o canto gregoriano: "Foi aqui em Capri que recebi a tua última [carta] de $1^{\circ}$ deste [mês]. Ainda tenho de voltar a Roma, vou concluir um pequeno curso de cantochão, faux-bourdon, [e] recordar os meus estudos de contraponto" (apud Pereira 2007, p. 63-64; Vidal 2014, p. 236). Em Roma, Nepomuceno teve aulas também com dois importantes nomes do cenário musical italiano, Eugenio Terziani (1824-1889) e Cesare De Sanctis (1824-1916), sendo este último também um compositor de música sacra. Nos quatro anos seguintes, Nepomuceno estuda em Berlim, na Akademie der Künste (1891-1892), com Heinrich von Herzogenberg (1843-1900), e no Stern'sches Konservatorium 
der Musik (1892-1894), com Arno Kleffel (1840-1913). Nesse período de formação germânica, Nepomuceno toma contato com o contraponto modal de Palestrina por meio do famoso tratado de Heinrich Bellermann (1832-1903), obra que chegou a traduzir parcialmente ao Português e que possivelmente lhe aproximou do ideal estético de construção melódica nos moldes do contraponto palestriniano (Vidal 2014, p. 254-255). Enfim, Nepomuceno encerra seu período de formação na Europa com uma estada em Paris, estudando órgão com Alexandre Guilmant (1837-1911), na Schola Cantorum, instituição esta fundada em 1894 por Charles Bordes (1863-1909), pelo próprio Guilmant e por Vincent d'Indy (1851-1931). Os três fundadores tinham o mesmo ideal de recuperar a música religiosa gregoriana e palestriniana.

Em terceiro lugar, na sua proximidade ao movimento de resgate da obra musical do Pe. José Maurício Nunes Garcia (1767-1830). Na mesma coluna do Jornal do Commercio em que propunha um movimento pela restauração da música sacra no Rio de Janeiro, Rodrigues Barbosa também fazia menção e louvava a atuação do Visconde de Taunay (1843-1899) no trabalho de resgatar e divulgar as composições musicais do Pe. José Maurício. Já se notava o envolvimento de Nepomuceno em tal processo reduzindo para piano e harmônio o famoso Requiem. Importante e representativo evento nesse sentido foi também a atuação de Nepomuceno nas cerimônias religiosas de consagração (26/06/1898) e inauguração (10/07/1898) da Igreja da Candelária no Rio de Janeiro, ocasiões em que regeu obras de Pe. José Maurício (Gazeta de Notícias, Rio de Janeiro, 27/06/1898; 02/07/1898; 07/07/1898).

Em quarto lugar, na sua atuação em prol da regulamentação da música sacra na Arquidiocese do Rio de Janeiro. Rodrigues Barbosa na sua coluna “Theatros e Música" do Jornal do Commercio, em edição do dia 7 de outubro de 1895, lançava publicamente a ideia de uma restauração da música sacra nas igrejas católicas do Rio de Janeiro. Propõe recuperar a dignidade austera e a elevação artística na música das cerimônicas católicas, por meio de uma recuperação do canto gregoriano, da polifonia de Palestrina e incentivando um trabalho conjunto de católicos e artistas do Rio de Janeiro. O primeiro nome a manifestar adesão à proposta foi justamente Alberto Nepomuceno, por meio de quatro cartas distintas publicadas pelo Jornal do Commercio em 9, 11, 13 e 15 de outubro de 1895. 
Finalmente, em quinto lugar, há as próprias composições musicais de Nepomuceno com caráter religioso, cuja abordagem analítica é o objeto do presente artigo.

\section{Música religiosa de Nepomuceno: uma proposta de classificação}

O Catálogo geral elaborado por Sérgio Alvim Nepomuceno Correa, neto de Nepomuceno, é ainda hoje a principal referência para organização da obra do compositor. Correa optou pela sistematização baseada na instrumentação utilizada pelo compositor e não na ordem cronológica (Correa 1996, p. 42-53). Procedendo-se à análise das obras sacras e religiosas de Nepomuceno, quanto ao "uso litúrgico" e quanto ao "texto empregado", chegamos a uma classificação sistemática de tais peças. Identificamos, assim três categorias distintas: (1) música instrumental religiosa; (2) oratório em sentido "lato"; e (3) música sacra. À primeira categoria pertence as peças Offertoire (órgão, 1912) e Cloches de Noël [Sinos de Natal] (piano, 1915). À segunda categoria pertencem as peças Ave Maria [texto de X. Silveira Jr.] (canto e piano, 1887), Ave Maria [texto de J. Galeno] (coro feminino, 1897), Ingemisco (canto e piano, 1899), Em Bethleem (canto, coro e orquestra, 1903), Canto nupcial (canto e piano, 1907) e Invocação à Cruz (coro e piano, s.d.). À terceira categoria pertencem as peças Canto fúnebre (coro, 1896), $O$ salutaris hostia (canto e órgão, 1897), Panis angelicus (duas vozes e órgão, 1909), Ecce panis angelorum (duas vozes e órgão, 1911), O salutaris hostia (coro feminino, 1911), Tantum ergo (coro e órgão, 1911), Missa (coro e órgão, 1915) e Ave Maria (canto e órgão, s.d.).

A primeira categoria justifica-se intuitivamente pelo título e pela instrumentação de Offertoire e pelo caráter religioso explicito atribuído à peça Cloches de Noël, o que é verificável pelas várias categorias de intertextualidade identificadas, sobretudo a citação literal com intenção referencial de um canto gregoriano no interior da peça. Tanto Offertoire como Cloches de Noël são peças de concerto e não necessariamente restritas a eventual uso litúrgico.

A segunda categoria é indicada como "oratório em sentido lato" porque inclui peças líricas de concerto ou música incidental com temática religiosa. Fazemos, assim, uma distinção em relação ao "oratório em sentido estrito", que seria aquele produzido contemporaneamente a Nepomuceno no contexto europeu, a saber, a música não encenada para canto, coro e orquestra com diferentes números musicais (independentes ou contínuos) e libreto sobre texto 
de tradição religiosa cristã. A obra Em Bethleem, classificada por Correa como oratório, na verdade é música incidental, já que é parte integrante de uma verdadeira ação teatral, de modo que sua própria execução fora do contexto cênico é praticamente inviável. Entre as demais peças, encontram-se duas peças destinadas a coro (Ave Maria e Invocação à Cruz) e três canções para canto e piano, sendo duas em Português (Ave Maria, Canto nupcial) e uma em Latim (Ingemisco).

A terceira categoria inclui as peças para voz solista ou para coro com texto latino e litúrgico, e cuja instrumentação e caráter enquadram-se nas exigências eclesiásticas para um uso real na Liturgia católica. Pode-se, por isso mesmo, considerar este último grupo de oito peças como sendo de música funcional, em contraposição a uma hipotética arte pela arte.

$\mathrm{Na}$ Tab. 1 indicamos a lista completa das obras sacras e religiosas de Nepomuceno.

\begin{tabular}{|c|c|c|}
\hline INSTRUMENTAÇÃO & PEÇA & CLASSIFICAÇÃO \\
\hline Piano & 1. Cloches de Noël, 1915. & música instrumental religiosa \\
\hline Órgão ou harmônio solo & 2. Ofertório, 1912. & música instrumental religiosa \\
\hline Canto e piano & $\begin{array}{l}\text { 3. Canto Nupcial,1907. } \\
\text { 4. Ave Maria em lá menor, s.d. } \\
\text { 5. Ingemisco, } 1899 \text { ? }\end{array}$ & $\begin{array}{l}\text { oratório (sentido "lato") } \\
\text { oratório (sentido "lato") } \\
\text { oratório (sentido "lato") }\end{array}$ \\
\hline $\begin{array}{l}\text { Canto e órgão ou } \\
\text { harmônio }\end{array}$ & $\begin{array}{l}\text { 6. Ave Maria em mi menor, s.d. } \\
\text { 7. O salutaris hostia, } 1897 \text { ? }\end{array}$ & $\begin{array}{l}\text { música sacra } \\
\text { música sacra }\end{array}$ \\
\hline Orquestra, coro e solistas & 8. A Pastoral [Em Bethleem], 1902. & oratório (sentido "lato") \\
\hline Coro & $\begin{array}{l}\text { 9. Canto fúnebre, } 1896 . \\
\text { 10. Ave Maria em ré maior, } 1897 . \\
\text { 11. Panis angelicus, } 1909 . \\
\text { 12. Ecce panis angelorum, } 1911 . \\
\text { 13. O salutaris hostia, } 1911 . \\
\text { 14. Tantum ergo, } 1911 . \\
\text { 15. Missa em ré menor, } 1914 . \\
\text { 16. Invocação à Cruz, s.d. }\end{array}$ & $\begin{array}{l}\text { música sacra } \\
\text { oratório (sentido "lato") } \\
\text { música sacra } \\
\text { música sacra } \\
\text { música sacra } \\
\text { música sacra } \\
\text { música sacra } \\
\text { oratório (sentido "lato") }\end{array}$ \\
\hline
\end{tabular}

Tabela 1: Composições sacras e religiosas de Alberto Nepomuceno; FONTE: O autor (2020)

\section{Intertextualidade musical: uma proposta analítica}

No presente artigo procuramos apresentar casos de intertextualidade musical encontrados em tal recorte da obra de Alberto Nepomuceno. Para tanto, recorremos a algumas abordagens já existentes em alguns autores quanto à classificação das categorias de intertextualidade.

Originalmente oriundo da crítica literária, o termo "intertextualidade" refere-se ao âmbito de possíveis relações de semelhança entre textos diversos, 
desde o empréstimo até o compartilhamento de estilos. No âmbito estritamente musical, a partir dos anos 80 do século XX se procurou transpor tal teoria para o contexto das citações ou alusões estilísticas dentro de uma obra musical (Burkholder 2001). Os autores que têm se dedicado à questão da intertextualidade musical costumam indicar algumas categorias de classificação para os diferentes níveis de semelhança entre obras ou estilos musicais diversos. Não há, entretanto, uma uniformidade quanto à nomenclatura empregada e ficase muitas vezes restrito a uma replicação de termos oriundos da teoria literária, mas sem a devida adequação ao campo específico da análise musical.

Em Remaking the past: musical modernism and the influence of the tonal tradition, J. N. Straus faz uma abordagem da música do século XX considerandoa enquanto obras estilisticamente progressistas, mas permeadas por sonoridades, formas e gestos musicais tradicionais. Identifica, então, três modelos de influência artística e apresenta uma lista de oito estratégias, análogas àquelas que o crítico literário Harold Bloom (1930-2019) chama de "razões revisionárias", e que teriam sido utilizadas pelos compositores do século $\mathrm{XX}$ para a releitura do passado: motivização, generalização, marginalização, centralização, compressão, fragmentação, neutralização e simetrização. Segundo Straus, "tais estratégias, mais do que qualquer estrutura musical específica, define uma prática comum [musical] do século XX" (Straus 1990, p. 17, tradução nossa).

Dentro da produção musicológica brasileira, destacamos, como possível referência teórica para a intertextualidade musical, o artigo "A intertextualidade musical como fenômeno", de Barbosa e Barrenechea. Os autores discutem qual seria o processo analítico conveniente para se estudar a influência musical e demonstrar a intertextualidade em música, propondo, então, sete categorias de intertextualidade musical: entidades orgânicas elementares, extrato, idiomática, paráfrase, estilo, paródia e reinvenção (Barbosa; Barrenechea 2003, p. 133-134; idem, 2005).

Em "Posibilidades intertextuales del dispositivo musical", O. Corrado descreve a intertextualidade como um termo oriundo da teoria literária do russo M. Bakhtin (1895-1975) e como sendo referente ao conjunto de relações demonstráveis no interior de um dado texto, aproximando-o a outros textos do mesmo autor ou a modelos literários aos quais pode fazer referência. No caso da música, Corrado distingue duas grandes áreas: a 1) área intrassemiótica, que contém os fatos produzidos com meios estritamente musicais; e a 2) área 
intersemiótica, que reúne fenômenos derivados de relações com outros discursos (linguagem verbal imagem etc.) (Corrado 1992, p. 34). A intertextualidade musical propriamente dita diria respeito à área intrassemiótica, na qual Corrado identifica três grandes categorias: (1) Citação de materiais geradores ou de esquemas formais (ex: missas ou motetos medievais construídos a partir de um "cantus firmus"); (2) Citação estilística, falsa citação ou citação sintética: reconstituição de gestos formais e expressivos dominantes de um estilo, mas sem referência a uma obra em particular (ex: paródia estilística, pastiche, neoclassicismo do início do século XX etc.); (3) Citação textual: incorporação de materiais temáticos reconhecíveis (melodias ou complexos polifônicos) tomados de uma determinada obra preexistente: auto-citação, transcrição criativa ou empréstimo temático; e citação com intenção referencial (Corrado 1992, p. 34-40).

Em “Música e intertextualidad", R. López Cano remete-se ao conceito de intertextualidade introduzido por Julia Kristeva e entende intertexto como o conjunto de textos que se relacionam com aquele que presentemente seja objeto de atenção e leitura (López Cano 2007, p. 31). Aplicando tal concepção para o campo da música, o autor identifica cinco categorias de intertextualidade: (1) a citação: referência, em um dado momento de uma obra musical, a uma outra obra concreta do próprio compositor ou de outro; (2) a paródia: uso de um tema, fragmento ou ideia de uma obra específica, mas apenas como ponto de partida para uma nova composição; (3) a transformação de um original: a revisão, o arranjo ou uma versão que um compositor faz de uma obra alheia; (4) as tópicas: a referência feita em uma obra a um estilo, gênero, tipo ou classe de música diferente, mas não a uma obra específica; e (5) a alusão: referência vaga a um estilo geral de um compositor ou a um tipo de música específico (López Cano 2007, p. 31-36). É peculiar de López Canto considerar entre as categorias de intertextualidade musical as "tópicas", conceito introduzido por L. Ratner em seu estudo Classic Music: Expression, Form and Style. As tópicas designam aqueles padrões referenciais que funcionam em um dado repertório como símbolo ou representação de algo: "matéria para o discurso musical representando afetos ou ideias específicas claramente reconhecíveis aos ouvintes contemporâneos à obra considerada" (Ratner 1980, p. 9, tradução nossa).

Apresentamos aqui uma breve consideração sobre aquelas tópicas que alguns autores identificaram como características especificamente do Romantismo do século XIX, uma vez que é nesse contexto estético que 
Nepomuceno, a princípio, está inserido. Para tanto, tomamos como referência o artigo "The Topical Vocabulary of the Nineteenth Century", de J. Dickensheets. Essas tópicas do Romantismo dividem-se em três grupos: tipos, estilos e dialetos. Os "tipos" incluem um mínimo de gestos, geralmente focando sobre elementos rítmicos associados com um movimento físico para, assim, definir-se um caráter musical (ex: minuto, giga e marcha). Os "estilos" incluem uma mistura de gestos que evocam um afeto ou trazem à mente algo extramusical (ex: estilo militar, música de caça, estilo pastoral, estilo fantasia, estilo de canto, estilo de canção, estilo de noturno, estilo de ária, estilo "appassionato", estilo virtuosístico etc.). Os "dialetos", enfim, são mais complexos, geralmente incluindo ampla gama de gestos e também outros estilos, visando-se evocar, assim, fortes associações extramusicais (ex: cavalheiresco, bardo e exótico) (Dickensheets 2012, p. 101131).

Considerando-se, pois, essas diferentes abordagens das categorias de intertextualidade, pode-se verificar que não há uma uniformidade quanto à nomenclatura analítica utilizada. Propormos uma breve discussão e uma síntese sobre as referidas categorias.

Entendemos que uma das dificuldades encontradas na categorização das relações musicais intertextuais deve-se à ausência de sistematização quanto às diferentes escalas envolvidas na análise dita intertextual. Um possível meio de se remediar isso seria organizar as categorias intertextuais conforme o nível estrutural em que se aplicam dentro de uma obra musical.

O primeiro e menor nível estrutural em que há uma categoria intertextual é o do "motivo", entendido como um pequeno fragmento melódico utilizado como elemento primário da composição musical, geralmente restrito a um único compasso e caracterizado por um contorno melódico e pelo padrão rítmico (Green 1979, p. 31). Nesse âmbito da forma musical, tem-se a primeira e a segunda categorias de Straus, a motivização e a generalização, nas quais um conteúdo motívido de uma obra é intensificado ou inserido em um novo conjunto de altura em uma nova obra. A primeira categoria de Barrenechea é a chamada entidades orgânicas elementares, em que um elemento musical de pequena dimensão é utilizado em outro contexto musical. Corrado não apresenta uma categoria intertextual explicitamente destinada ao nível motívico, entretanto esse nível é abarcado na citação com intenção referencial, em que se utilizam fragmentos de obras precedentes. A primeira categoria de López Cano, a citação, 
diz respeito à referência que uma dada obra faz a um trecho de uma obra precedente, ainda que não se restrinja ao nível motívico.

O segundo nível estrutural em que se dá as relações intertextuais é o da frase musical ou dos períodos musicais. Pode-se entender a frase musical como uma unidade estrutural que expressa um pensamento musical mais ou menos completo e que atinge um ponto de relativo repouso por meio de fórmulas cadenciais. No nível do período musical, isto é, daquela unidade formal constituída por várias frases, encontra-se comumente o "tema", aquela ideia musical completa, traduzida em um sentido de completude melódica, rítmica e harmônica, pela qual o trecho se apresenta como um elemento íntegro e definidor do caráter musical (Cf. Green 1979, p. 7-8; 50; Bas 1957, p. 164; Schoenberg 2012, p. 29-30; 48).

De Corrado, tem-se a citação de materiais geradores, por exemplo, uma frase musical utilizada como "cantus firmus" em outra, e a citação com intenção referencial, que é a utilização de fragmentos de obras. De López Cano, há a paródia, que é a utilização de um fragmento de obra específica enquanto ponto de partida para uma nova composição.

A maioria das categorias intertextuais, entretanto, recaem sobre o nível temático. Em Corrado tem-se a auto-citação, que é o aproveitamento do material temático de obras precedentes; o empréstimo temático, que é o uso de um tema musical para a elaboração de uma obra original; e, enfim, a citação com intenção referencial, que certamente recai sobre o caráter temático de trechos musicais de obras preexistentes. Em López Cano, a noção de citação parece ser mais bem apropriada a este âmbito do período musical em seu caráter de tema, uma vez que o próprio autor indica que a referência em tal caso deve ser forte, evidente e facilmente reconhecível, o que é inerente à noção de tema musical. Também a categoria de paródia recai sobre a ideia de tema, seja como ponto de partida para a nova composição seja como substrato para reelaboração geral. De Barrenechea tem-se o extrato e a paráfrase como categorias apropriadas ao nível temático.

No último grau de complexidade formal na estruturação musical estão os períodos binários ou ternários combinados em agrupamentos maiores e constituindo, então, as grandes seções que configuram as obras musicais enquanto tais (Green 1979, p. 73s). Para esse nível mais amplo de organização formal, os autores supracitados reservam também algumas categorias de intertextualidade. Trata-se aqui, pois, da citação que uma obra faz não mais de 
elementos motívicos ou temáticos, mas sim de esquemas formais amplos ou mesmo de reinvenções e transcrições que abrangem uma obra preexistente considerada em sua integralidade. De Barrenechea tem-se a paródia (recriação ou subversão de uma obra musical) e a reinvenção (releitura livre de uma obra preexistente, mas visando efeito antagônico). De Corrado, tem-se a citação de esquemas formais (apropriação deliberada de uma organização formal específica de obra preexistente) e a transcrição criativa (elaboração de uma nova obra a partir da transcrição explícita de uma obra anterior). De López Cano, finalmente, tem-se a transformação de um original (revisão, arranjo ou versão que um compositor faz de uma obra alheia).

Dessa discussão sobre as categorias intertextuais sob o viés da análise formal, chega-se, portanto, à síntese apresenta na Tabela 2 e que utilizaremos para a análise das peças de Alberto Nepomuceno no presente artigo.

\begin{tabular}{|c|c|c|c|}
\hline & $\begin{array}{l}\text { MICRO ESCALA } \\
\text { - motivos, semifrases e } \\
\text { frases }\end{array}$ & $\begin{array}{l}\text { MÉDIA ESCALA } \\
\text { - períodos, sentenças e } \\
\text { seções }\end{array}$ & \begin{tabular}{l}
\multicolumn{1}{c}{ MACRO ESCALA } \\
- obra completa ou \\
movimentos individuais
\end{tabular} \\
\hline Straus & $\begin{array}{l}\text { - Motivização } \\
\text { - Generalização }\end{array}$ & $x$ & $\mathrm{x}$ \\
\hline Barrenechea & $\begin{array}{l}\text { - Entidades orgânicas } \\
\text { elementares } \\
\text { - Extrato } \\
\text { - Paráfrase }\end{array}$ & $\begin{array}{l}\text { - Extrato } \\
\text { - Paráfrase }\end{array}$ & $\begin{array}{l}\text { - Paródia } \\
\text { - Reinvenção }\end{array}$ \\
\hline Corrado & $\begin{array}{l}\text { - Citação com intenção } \\
\text { referencial } \\
\text { - Citação de materiais } \\
\text { geradores }\end{array}$ & $\begin{array}{l}\text { - Auto-citação } \\
\text { - Empréstimo temático } \\
\text { - Citação com intenção } \\
\text { referencial }\end{array}$ & $\begin{array}{l}\text { - Citação de esquemas } \\
\text { formais } \\
\text { - Transcrição criativa }\end{array}$ \\
\hline López Cano & $\begin{array}{l}\text { - Citação } \\
\text { - Paródia }\end{array}$ & $\begin{array}{l}\text { - Citação } \\
\text { - Paródia }\end{array}$ & $\begin{array}{l}\text { - Transformação de um } \\
\text { original }\end{array}$ \\
\hline
\end{tabular}

Tabela 2: Categorias de intertextualidade musical nas três escalas formais; FONTE: O autor (2020)

As demais categorias de intertextualidade, não enquadradas na sistematização supracitada, não designam uma referência de uma dada obra a outra obra específica, mas sim a algo comum a determinado grupo de obras. Assim, portanto, são categorias que radicam no "dialeto" (estilo compartilhado por um grupo de compositores), no "idioma" (estilo de um determinado compositor) ou simplesmente em regras e estratégias compositivas (Cf. Meyer 1996).

\section{Sinos de Natal}


No repertório para piano produzido por Alberto Nepomuceno encontram-se diversas formas musicais-mazurcas, valsas, noturnos, suítes, sonata, tema e variações etc. - , mas apenas uma peça com conotação religiosa: Cloches de Noël (Sinos de Natal). Esse caráter religioso é sugerido já pelo título, mas é evidenciado pelo uso explícito da melodia de um canto gregoriano-a antífona “Hodie Christus natus est" - e pela alusão que o compositor faz à sonoridade dos sinos. A partitura manuscrita da composição foi publicada na edição de $1^{0}$ de janeiro de 1916 (Oitava do Natal) do jornal O Imparcial e foi dedicada pelo compositor aos príncipes Leopoldo e Carlos e à princesa Maria José, filhos do rei Alberto I da Bélgica. Sabe-se que Nepomueceno inseriu-a como peça de concerto em apresentações públicas suas (Cf. O Imparcial, Rio de Janeiro, 27/07/1917; Jornal do Commercio, Rio de Janeiro, 17/07/1917).

A peça se inicia com uma primeira seção constituída por três elementos:

Compassos 1 a 6: pedal Fá-Dó (mão esquerda) acompanhando um perfil descendente de sequências de terças e sextas desde a região aguda até a central do piano (mão direita) (Ex. 1);

Compassos 7 a 11: mesmo padrão na mão esquerda acompanhando um ostinato a duas vozes na mão direita (sonoridade com função de subdominante: Sol-Lá-Si b juntamente com Sol-Fá) (Ex. 2);

Compassos 12 a 23: continuação do ostinato da mão direita, mas como acompanhameno de uma melodia de caráter modal (mão esquerda) (Ex. 3).

Harmonicamente, esse trecho inicial apresenta um encaminhamento de Fá maior, no início, para o V grau de Ré menor, ou seja, configura-se uma tonicização na relativa menor.

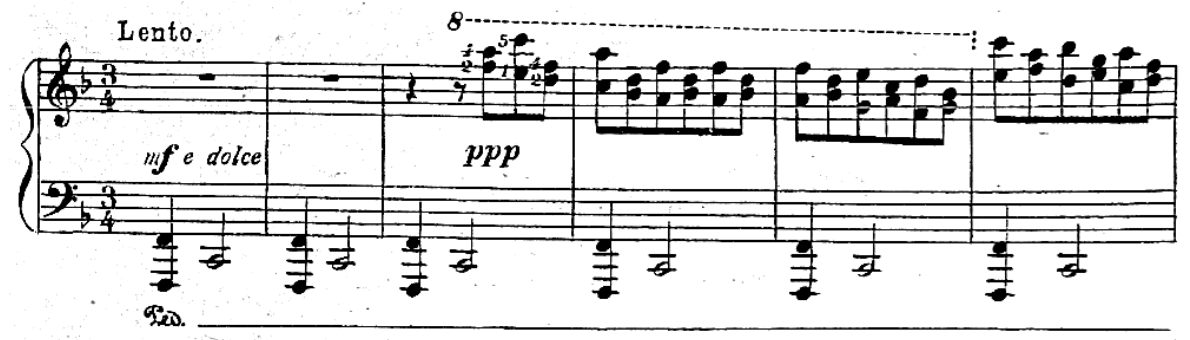

Exemplo 1: Nepomuceno, Cloches de Noël, c. 1-6; FONTE: Nepomuceno [1915a] 


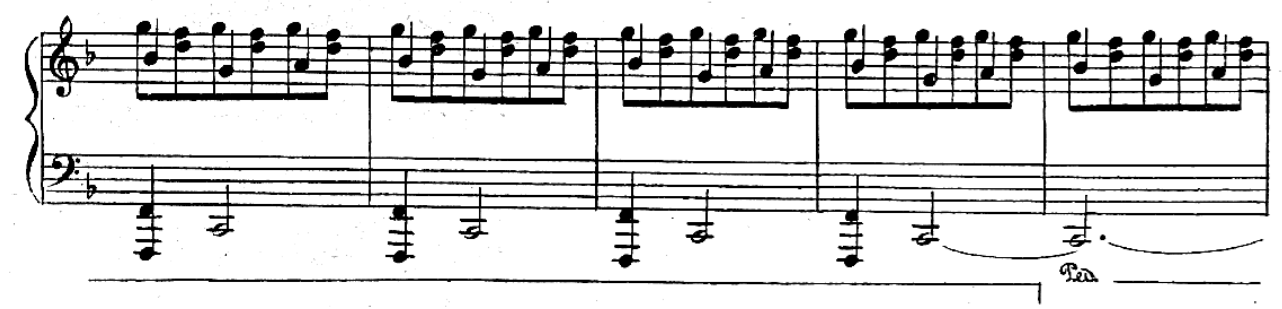

Exemplo 2: Nepomuceno, Cloches de Noël, c. 7-11; FONTE: Nepomuceno [1915a]
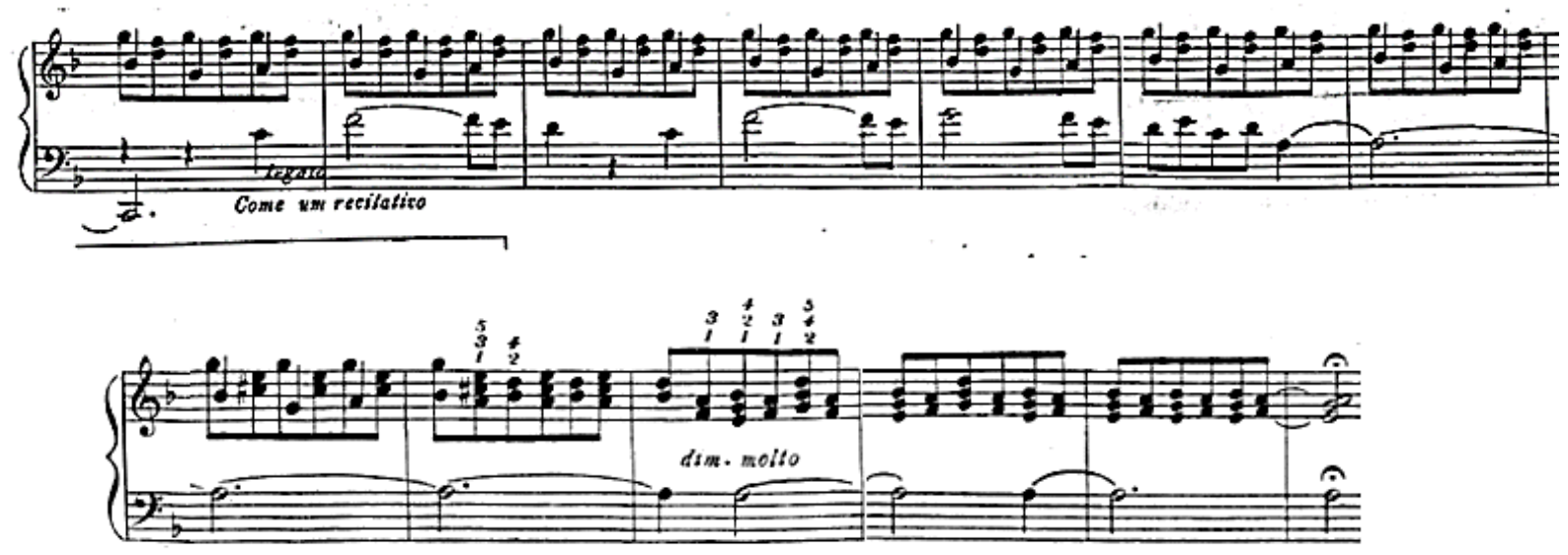

Exemplo 3: Nepomuceno, Cloches de Noël, c. 12-23; FONTE: Nepomuceno [1915a]

A segunda seção, compasso 24, é constituída por um trecho com ritmo livre e no qual há uma simples harmonização de um trecho de cantochão (Ex. 4), a antífona "Hodie Christus natus est", do Magnificat do Ofício de segundas Vésperas de 25 de dezembro (Natal) (Ex. 5). Entre os compassos 25 a 46, há uma terceira seção, que é estruturada da mesma forma que a primeira, com a diferença de que aqui a linha do pedal apresenta Ré-Lá, ou seja, indica que a música se desenvolve na relativa menor. No compasso 47 inicia-se uma quarta seção, semelhante à segunda, mas com a segunda parte da já citada antífona gregoriana, novamente harmonizada. A peça se encerra com uma quinta seção, entre compassos 48 a 82, semelhante novamente à primeira, com o uso de um pedal, terças-sextas sequenciadas, melodia modal e finalização com o ostinato da mão esquerda em "diminuendo" e "calando". 


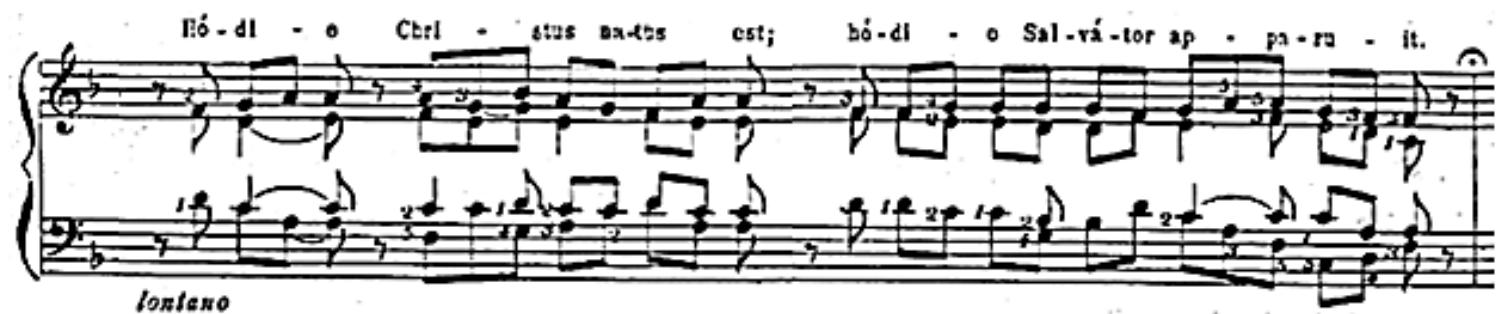

Exemplo 4: Nepomuceno, Cloches de Noël, c. 24; FONTE: Nepomuceno [1915a]

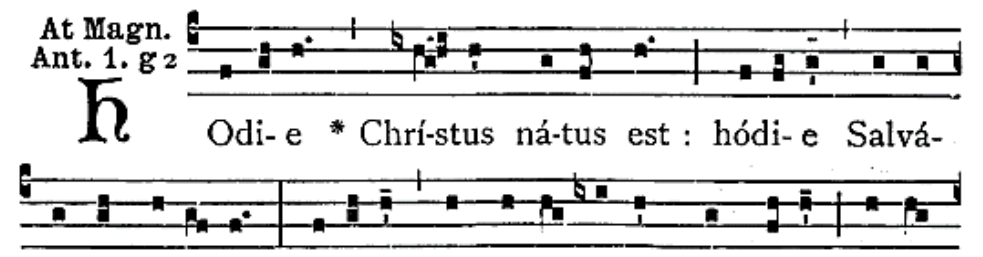

tor appáru- it : hódi-e in térra cánunt Ange-li, laetán-
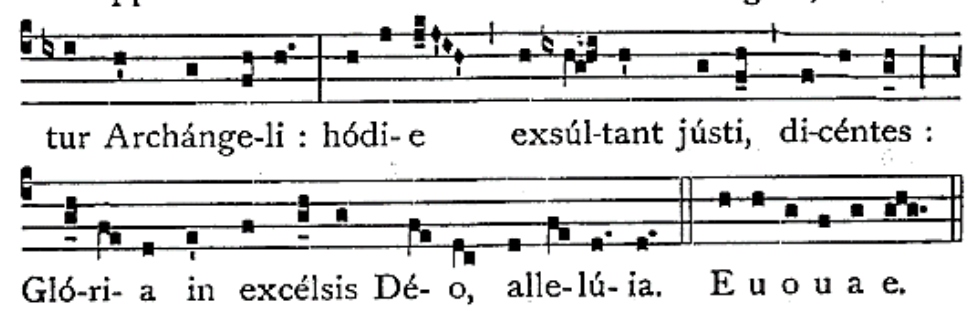

Exemplo 5: Antífona gregoriana Hodie Christus natus est; FONTE: “Liber usualis” (1961, p. 413)

O mencionado procedimento de inserir uma melodia gregoriana em uma obra instrumental de caráter religioso é um traço marcante na obra religiosa do compositor e pianista virtuose Franz Liszt (1811-1886). Nas peças Stabat Mater e Vexilla Regis, por exemplo, encontramos a estrutura formal que Nepomuceno também utiliza, a saber, a alternância de trechos de uma melodia gregoriana claramente identificável com episódios musicais diversos. Na primeira peça, Liszt insere a melodia inicial da Sequência gregoriana de Nossa Senhora das Dores, Stabat Mater (Ex. 6), e na segunda, o hino gregoriano Vexilla Regis Prodeunt. Em ambos a letra latina original é indicada na partitura sobre a melodia gregoriana, mesmo procedimento utilizado por Nepomuceno em Cloches de Noël. Dada tal proximidade de esquemas formais, identificamos aqui um primeiro tipo de intertextualidade musical, aquela chamada "citação de materiais geradores". 


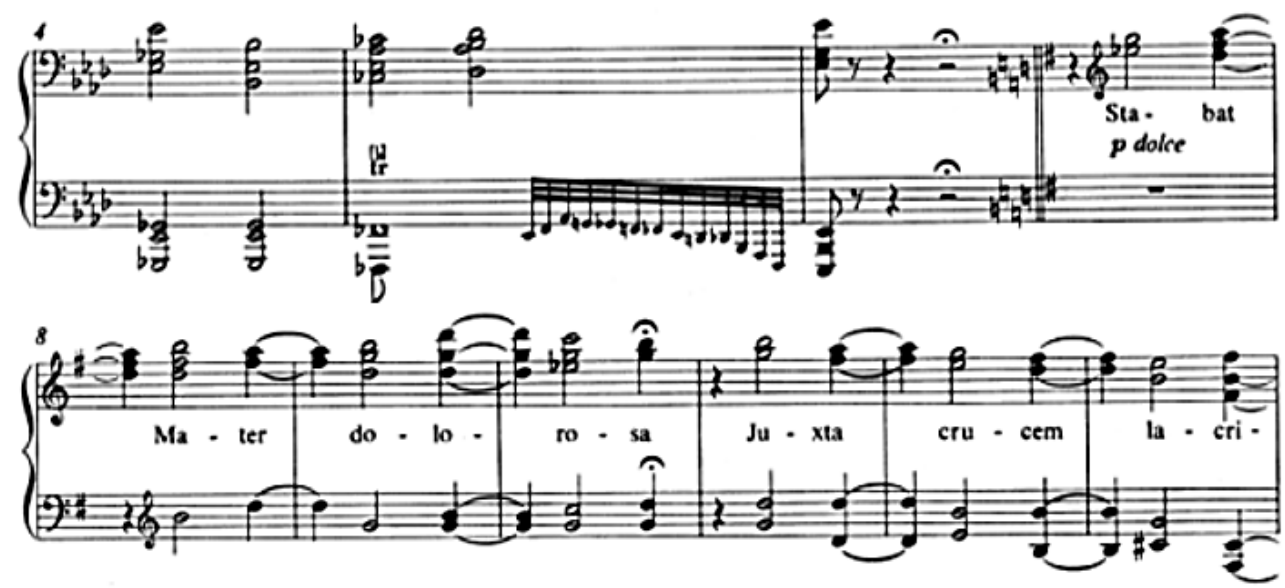

Exemplo 6: Liszt: Stabat Mater, c. 4-16; FONTE: Liszt (1978a)

No âmbito das frases musicais, estão presentes elementos que remetem diretamente ao estilo melódico do cantochão (modalismo, âmbito de alturas, tipos de intervalos etc.) e, como já indicado, cita-se literalmente um canto específico, a antífona gregoriana "Hodie Christus natus est". Há, assim, um outro tipo de intertextualidade: a "citação estilística" e a "citação textual com intenção referencial", em nível fraseológico.

No nível das pequenas células musicais, identificou-se ainda um tipo de harmonização ao referido cantochão idêntico ao empregado em contexto estritamente religioso. Trata-se de um procedimento comumente usado no final do século XIX e no início do século XX para acompanhar o canto gregoriano ao órgão. É descrito no Traité théorique et pratique de l'accompagnement du plain-chant de Louis Niedermeyer e Joseph d'Ortigue, publicado em 1856. Sucintamente, apontavam-se as seguintes regras para a harmonização do cantochão: 1) usar exclusivamente em cada modo as notas da escala; 2) usar frequentemente as tríades da nota final e da dominante de cada modo; 3) usar exclusivamente as fórmulas harmônicas próprias às cadências de cada modo; 4) não usar no acompanhamento do cantochão outro acorde senão as tríades consonantes e sua primeira inversão; 5) as leis que governam a melodia gregoriana [p.ex.: uso do $\mathrm{Si}$ b] devem ser observadas também em cada uma das quatro vozes do acompanhamento instrumental; 6) sendo a melodia o mais essencial do cantochão, ela deve sempre estar na voz superior do acompanhamento instrumental (Niedermeyer; D'ortigue, 1905, p. 14-16). Tais regras são seguidas por Nepomuceno nos trechos em que harmoniza a antífona gregoriana "Hodie Christus natus est". 
No mesmo nível micro-musical, encontramos também um uso idiomático do piano para se remeter o ouvinte à sonoridade dos sinos (Ex. 7), procedimento também encontrado no repertório pianístico religioso de Liszt, tal como em sua obra "Angelus!", primeira peça dos Annés de Pèlerinage (troisième anné), na qual se sabe que Liszt utiliza sequências repetidas e alternadas de oitavas, quartas, sextas e terças como sendo uma evocação dos sinos de Roma (Cf. Walker 1997, p. 394-396). Outro exemplo, mais explícito, é o da peça Abendglocken (Sinos da noite) no ciclo Weihnachtsbaum (Árvore de Natal), em que a própria temática religiosa e natalina fica evidente (Ex. 8 e Ex. 9). Tanto o emprego do recurso padrão de harmonização gregoriana como o uso idiomático para evocação dos sinos identificamos como sendo o tipo de intertextualidade dita "citação estilística", em nível motívico.

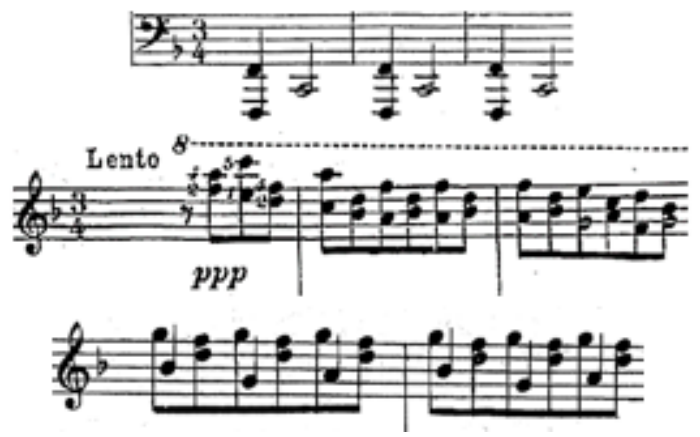

Exemplo 7: Nepomuceno, representação dos sinos em Cloches de Noël; FONTE:

Nepomuceno [1915a]

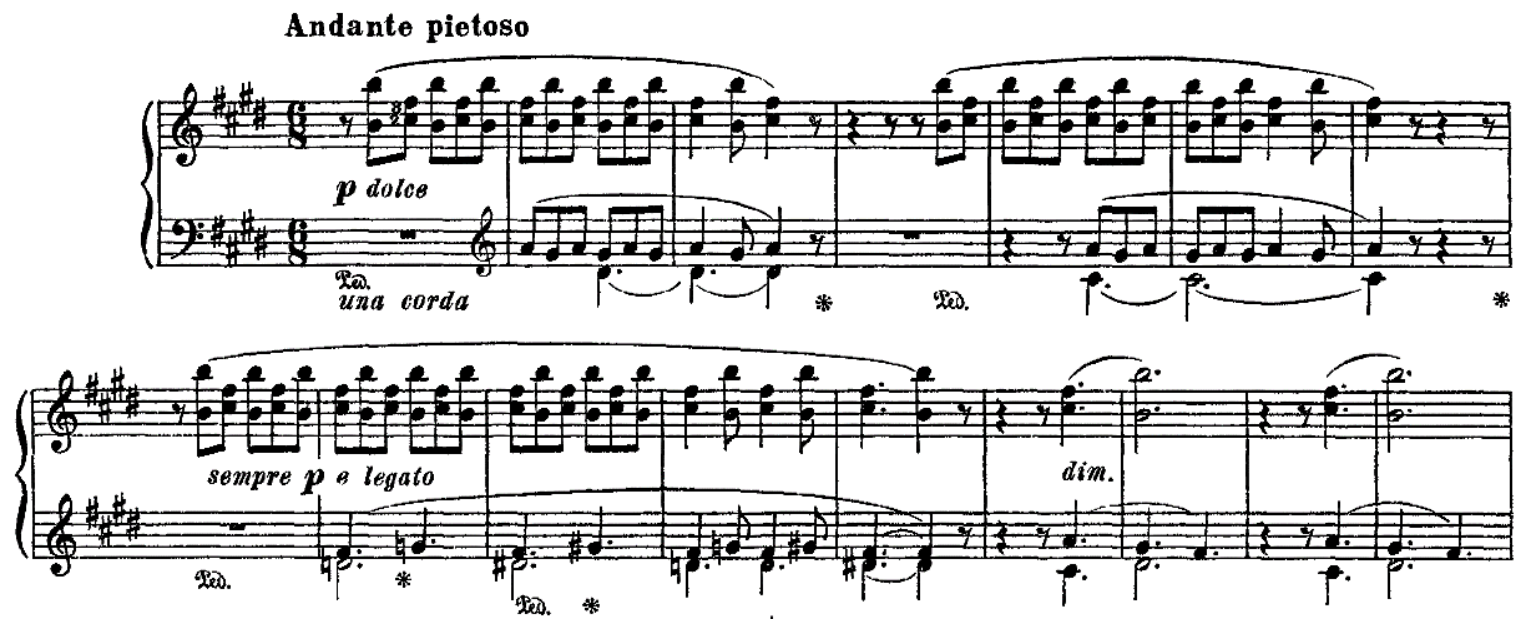

Exemplo 8: Liszt, representação dos sinos em Angelus!; FONTE: Liszt (1916) 


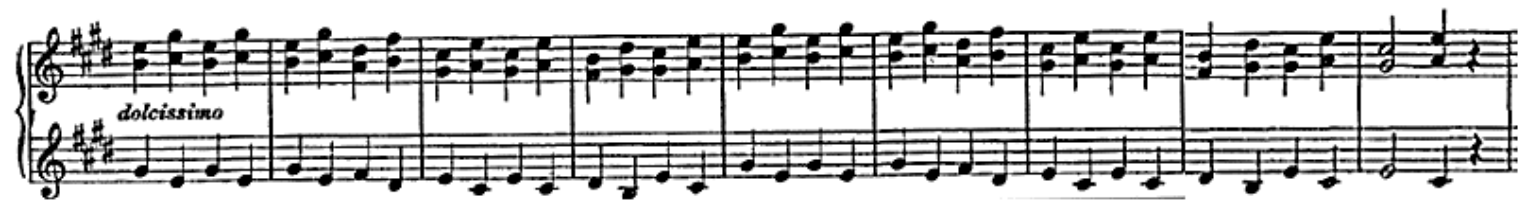

Exemplo 9: Liszt representação dos sinos em Abendglocken; FONTE: Liszt (1927)

Assim, pois, a análise de Cloches de Noël apontou para três níveis de relações intertextuais: (1) citação de materiais geradores, quando à forma geral; (2) citação estilística e citação textual com intenção referencial, em nível fraseológico; e (3) citação estilística, em nível motívico. A peça mostra-se, assim, como possivelmente o único exemplo musical em que Nepomuceno transpõe para a música instrumental de concerto a sua particular afeição ao canto gregoriano e às questões inerentes à música sacra católica.

\section{O oratório brasileiro}

Diferentemente do contexto europeu, em que a composição e execução pública de oratórios mantinha-se até o século XX como uma prática musical comum, no Brasil são poucos os exemplares de tal gênero musical. Monsenhor Schubert (1980, p. 40-41) faz uma relação dos oratórios brasileiros da primeira década do século XX, ali entendidos no sentido amplo de obras teatrais com temática religiosa e com importante intervenção da parte musical. Verifica-se que a lista não é tão ampla e um dos poucos exemplares é justamente uma obra de Alberto Nepomuceno: Em Bethleem.

Nessa obra, Nepomuceno utiliza como libreto o $3^{\text {o }}$ quadro da obra "Pastoral" do escritor brasileiro Henrique Maximiano Coelho Netto (1864-1934), composta em 1903 para ser encenada no Natal do mesmo ano na cidade de Campinas/SP. Musicalmente é formada por seis peças: "Prelúdio", "Coro dos Emoritas", "Coro dos Anjos", "Cantilena", "Coro dos Pastores" e "Final" (Tab. 2).
1) Prelúdio
Orquestra
2) Coro dos Emoritas
(Duração: 5 min.)
Coro a 4v. (S-A-T-B)
(Duração: 4 min.)
Antes da Cena 1
3) Coro dos Anjos
(sem cena)
Coro feminino (S1-S2-C1-C2)
(Duração: 2 min.)
Cena 3 (2 vezes) 

4) Cantilena
Ária para mezzo-soprano e orquestra
(Duração: $3 \mathrm{~min}$ )
Final da Cena 3
5) Coro dos Pastores
Coro masculino (T-B)
(Duração: 7 min.)
6) Final
Início da Cena 4
(Duração: 2 min.)
Final da Cena 4
(Encerramento da obra)

Tabela 2: Estrutura de Em Bethleem; FONTE: O autor (2020)

Nas peças que a constituem foram identificados elementos (1) da tópica pastoril (no "Prelúdio" e no "Coro dos Pastores"), (2) elementos representativos (no "Coro dos Anjos") e (3) categorias de intertextualidade musical (na "Cantilena").

Segundo Monelle, o "pastoralismo" é um dos gêneros culturais e literários mais antigos, abrangendo desde a poesia de Hesíodo (século VIII a. C.) até o movimento arcadiano e o culto à natureza no Romantismo. Há também um sentido religioso inerente à temática pastoral, já que na Sagrada Escritura (Bíblia) Jacó, Isaac, Abraão e Davi são descritos como pastores e o próprio Cristo se denomina o Bom Pastor, tendo também seu nascimento sido revelado primeiramente aos pastores (2006, p. 185; 198). Entre os procedimentos concretos empregados pelos compositores ao longo da história da música para se evocar esse sentido pastoral, Monelle identifica três, por ele chamados de "significantes pastorais" (2006, p. 207-209; 215):

- Instrumentos musicais de sopro, tais como flauta, oboé, clarinete e gaita de foles (com efeito típico de bordão), pois desde a Antiguidade a imagem clássica da música pastoril é o pastor com seu instrumento de sopro;

- Compasso composto típico da chamada "siciliana", fórmula de dança tradicional da Sicília, onde nasceu Teócrito, poeta líder do pastoralismo;

- Simplicidade rural, pois é comum associar-se aspectos de rudeza e ingenuidade com os costumes da gente simples do campo, o que musicalmente é representado por meio de perfis melódicos com âmbito restrito, de ritmo limitado a padrões constantemente repetidos, evitando-se graus distantes da escala e preferindo-se a tonalidade maior. 
Esses três significantes pastorais são encontrados claramente no "Prelúdio" de Nepomuceno. No próprio manuscrito da obra o compositor indicou sob o nome de "motivo pastoril" uma pequena frase musical para instrumentos de sopro, com apogiaturas e tercinas sobre um baixo a modo de bordão com um intervalo de quinta justa (Ex. 10). Esse motivo é empregado no início da obra com solos de oboé e de clarinete em uma fórmula rítmica com tercinas, gerando o tradicional efeito da siciliana pastoral (Ex. 11). Além disso, há ainda o elemento de "simplicidade rural" no tema a partir do compasso 14, com um baixo na forma de bordão e duas linhas melódicas, uma com graus conjuntos (violas) e outra constituída basicamente pelas notas da tríade da tônica (Ex. 12). Esse mesmo tema é depois apresentado em diferentes centros tonais, mostrandose, assim, como a ideia musical em torno da qual a peça se organiza. O tema inicial das violas, quase estritamente em graus conjuntos, será em seguida retomado no "Coro dos pastores", após uma introdução com o mesmo motivo pastoril da introdução do "Prelúdio" (Ex. 13).

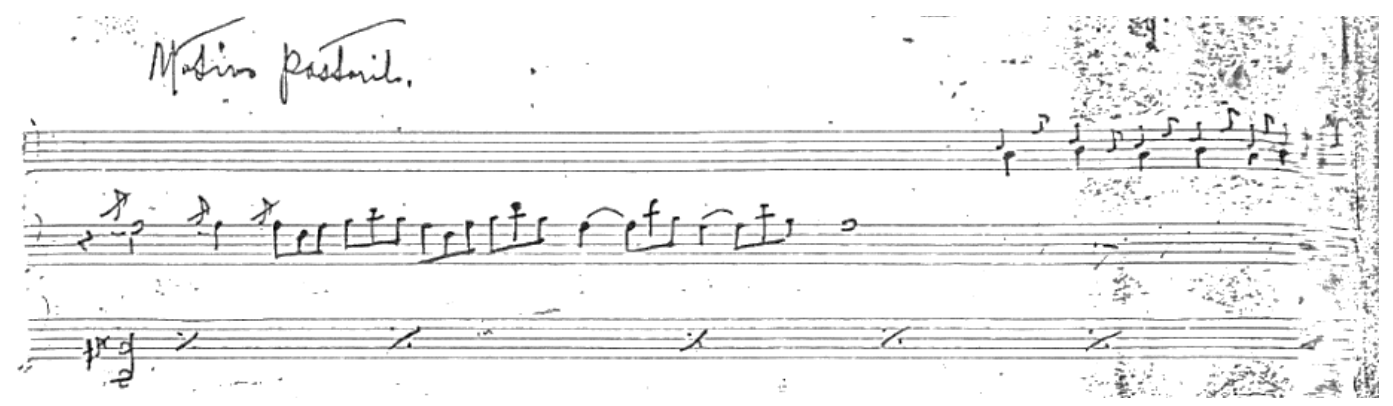

Exemplo 10: Nepomuceno, "motivo pastoril" no manuscrito de Em Bethleem; FONTE: Nepomuceno [1903] 

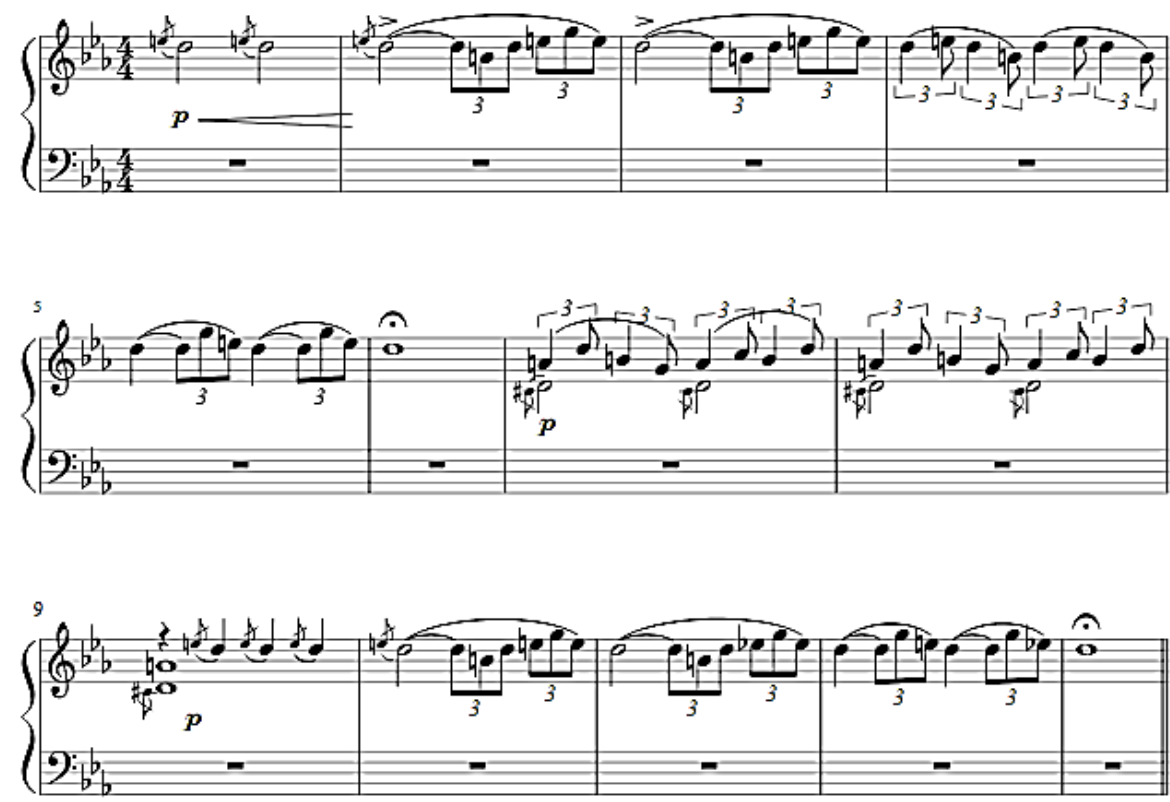

Exemplo 11: Nepomuceno, “Prelúdio" de Em Bethleem, c. 1-13; FONTE: O autor (2020)
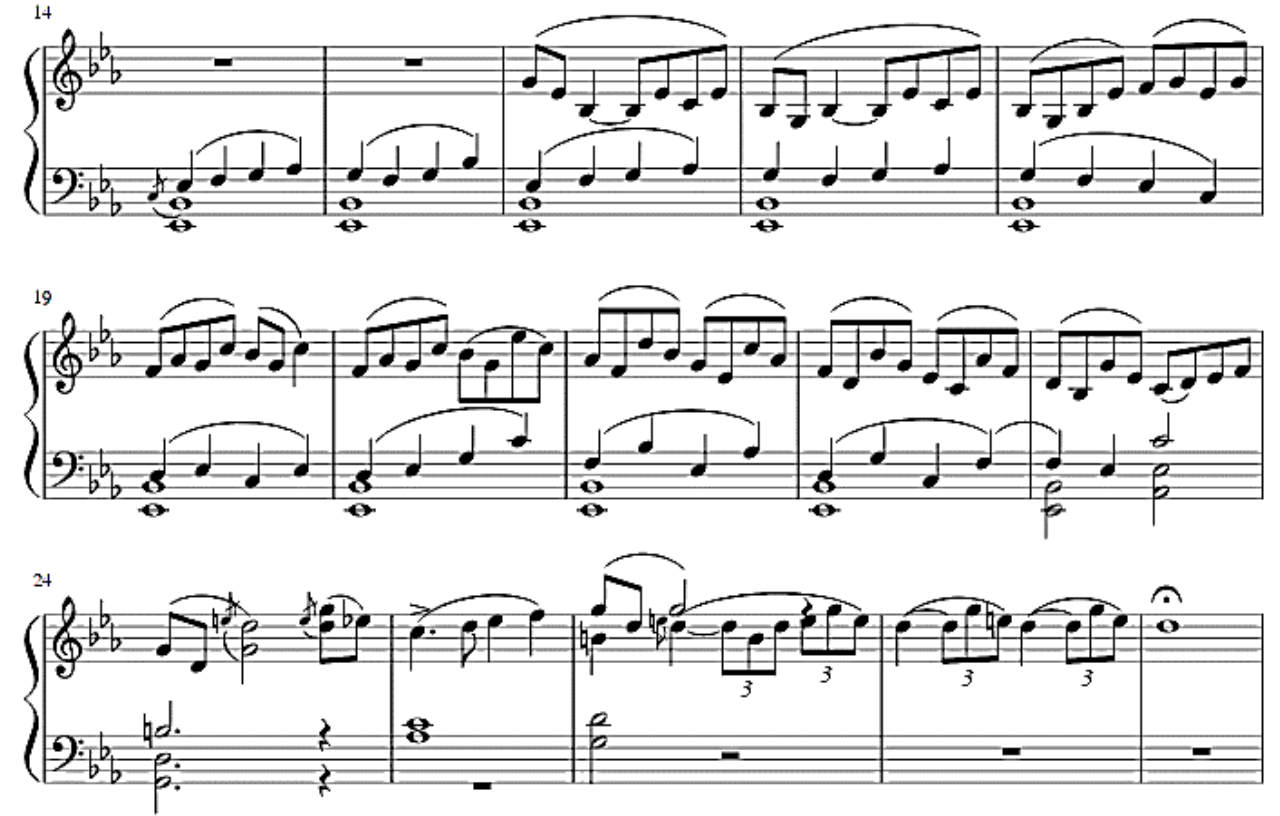

Exemplo 12: Nepomuceno, tema do "Prelúdio" de Em Bethleem, c. 14-28; FONTE: O autor (2020) 
MUSICA THEORICA Revista da Associação Brasileira de Teoria e Análise Musical 2020,

v. 5, n. 1, p. 196-241 - Journal of the Brazilian Society for Music

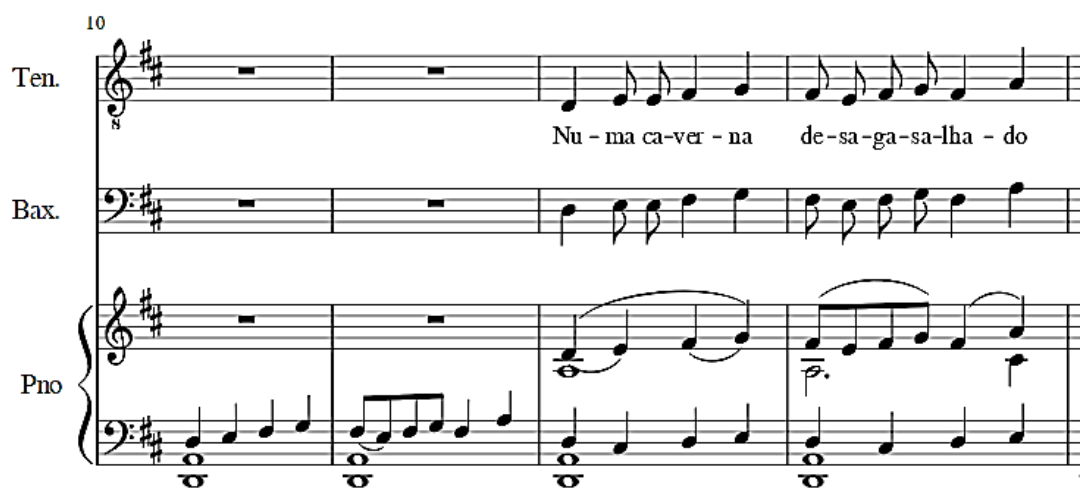

Exemplo 13: Nepomuceno, “Coro dos Pastores" de Em Bethleem, c. 10-13; FONTE: O autor (2020)

O uso das tópicas pastorais no "Prelúdio" de Nepomuceno remete a procedimentos compositivos encontrados em dois oratórios natalinos importantes do repertório europeu do século XIX. No $\mathrm{n}^{\mathrm{o}} 4$ do seu oratório Christus, na peça orquestral chamada "Hirtengesang an der Krippe", Liszt realiza a típica música pastoral religiosa, empregando a métrica 6/8, reservando a introdução da peça unicamente para solos de oboé e clarinete, e também elaborando linha melódica temática para o clarinete do compasso 26 em diante, além de utilizar o efeito de notas sustentadas com os intervalos de quinta entre as notas do oboé e do fagote (Ex. 14). No "Prélude" do Oratorio de Noël de SaintSaëns, encontra-se o típico compasso pastoril, o 12/8, com decorrentes figuras pontuadas e desenhos melódico-rítmicos próprios da siciliana (Ex. 15). 

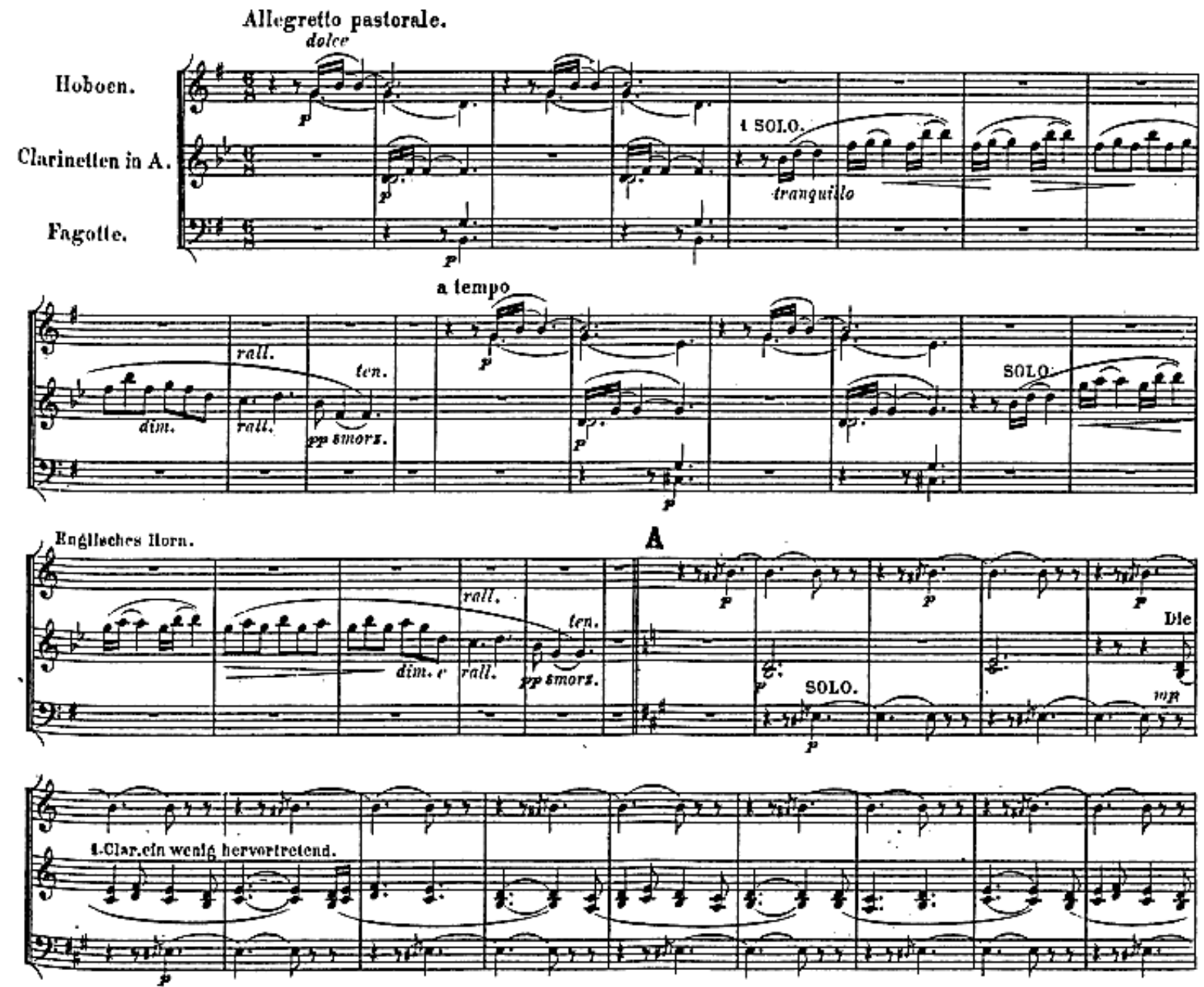

Exemplo 14: Liszt, início de "Hirtengesang an der Krippe" do oratório Christus; FONTE: Liszt (1872)

Allegretto pastorale.
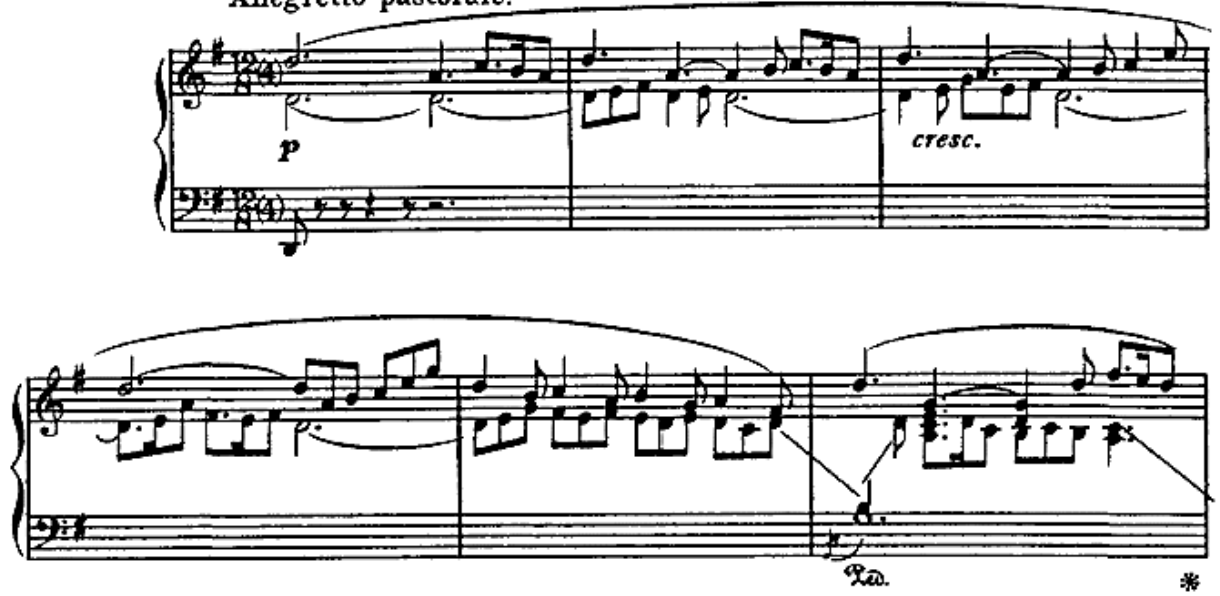

Exemplo 15: Saint-Saëns, “Prelúdio” do Oratório de Noël; FONTE: Saint-Saëns (1891) 
O "Coro dos Anjos" é uma peça para coro "a cappella" apenas para vozes femininas. É formado por dois períodos musicais, sendo o primeiro direcionado harmonicamente da tônica para a dominante (c. 1-11) com o texto "Glória a Deus nas alturas" repetido três vezes; e o segundo período retornando à tônica, com a letra "Na terra paz aos homens de boa vontade". A declamação do texto é praticamente silábica, havendo clara adequação dos perfis melódicos à prosódia do texto. A peça é inteiramente diatônica, utilizando o compositor um contraponto tonal de $1^{\underline{a}}$ e $2^{2}$ espécies, com amplo predomínio de consonâncias (Ex. 16).

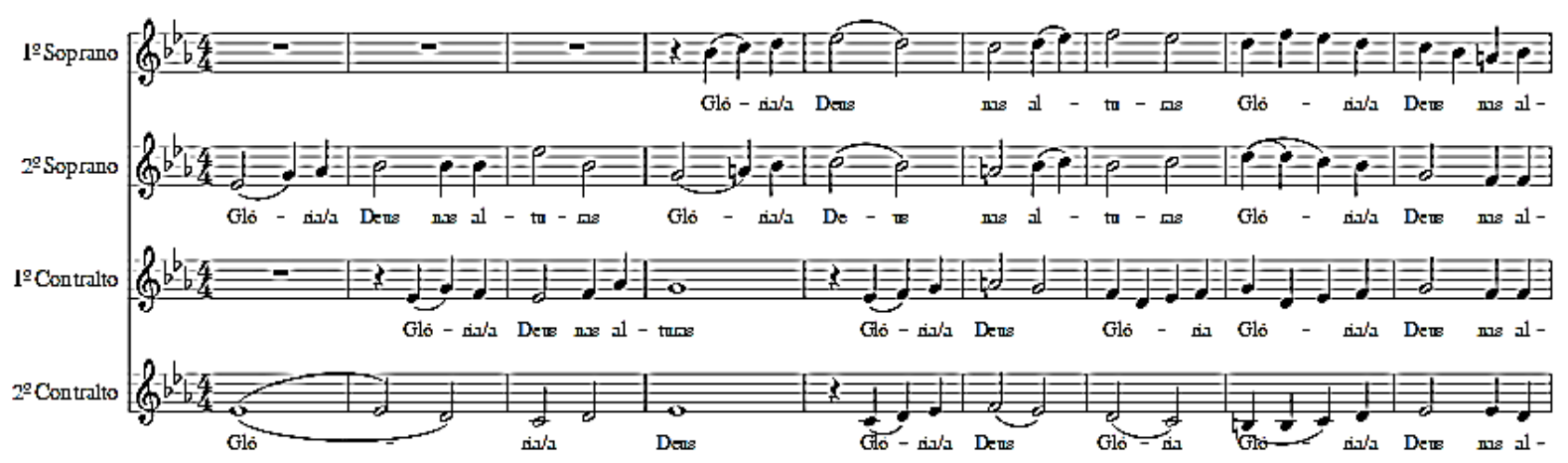

Exemplo 16: Nepomuceno, “Coro dos Anjos" de Em Bethleem, c. 1- 9; FONTE: O autor (2020)

Em termos intertextuais, a peça apresenta um recurso "representativo" já tradicional no repertório de Oratório. Trata-se da representação musical de personagens espirituais por meio de procedimentos que remetam o ouvinte à polifonia clássica contrapontística, tradicionalmente empregada na música sacra, litúrgica. Dentro do contexto específico do Natal, é comum a utilização de vozes femininas e de uma textura coral para se representar o canto dos anjos por ocasião do nascimento de Cristo.

No n 2 do oratório Christus, por exemplo, após um solo de soprano com o cantochão "Angelus ad pastores", Liszt insere o "Gloria in excelsis Deo" em uma escrita musical próxima àquela utilizada por Nepomuceno: coral feminino (soprano e contralto) a 4 vozes e quase "a cappella", já que a orquestração prevê basicamente um dobramento das notas do coro por instrumentos de sopro. Liszt opta, contudo, por uma textura homofônica (Ex. 17). Em Natale del Redentore, Lorenzo Perosi (1872-1956) dá a seu "Inno Angelico" tratamento vocal semelhante ao empregado por Nepomuceno: coro feminino a quatro vozes (2 sopranos e 2 contraltos), sendo a textura totalmente homofônica e a declamação 
do texto também silábica. O compositor italiano opta, contudo, por uma ampla orquestração no sentido de reforçar o caráter sublime de tal passagem (trilo das cordas, timbre da harpa e figurações melódicas do flautim entre as frases corais) (Ex. 18).
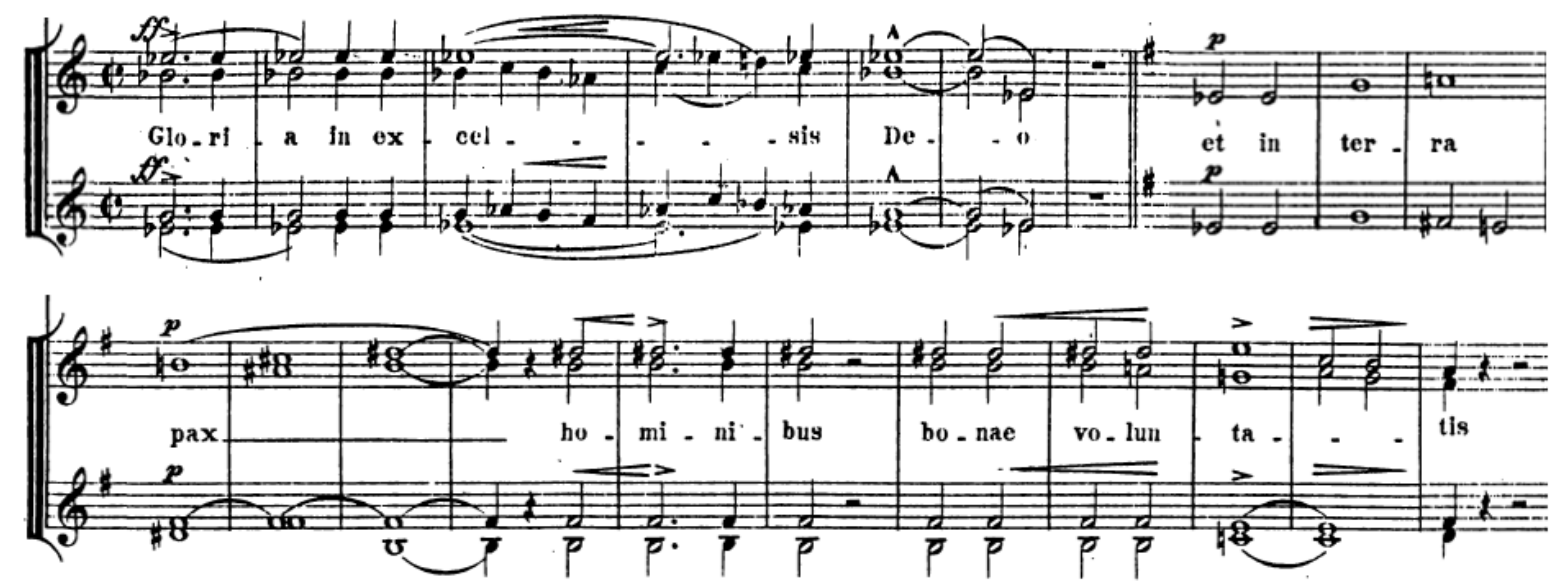

Exemplo 17: Liszt, Oratório Christus, nํㅡㄹ FONTE: Liszt (1872)

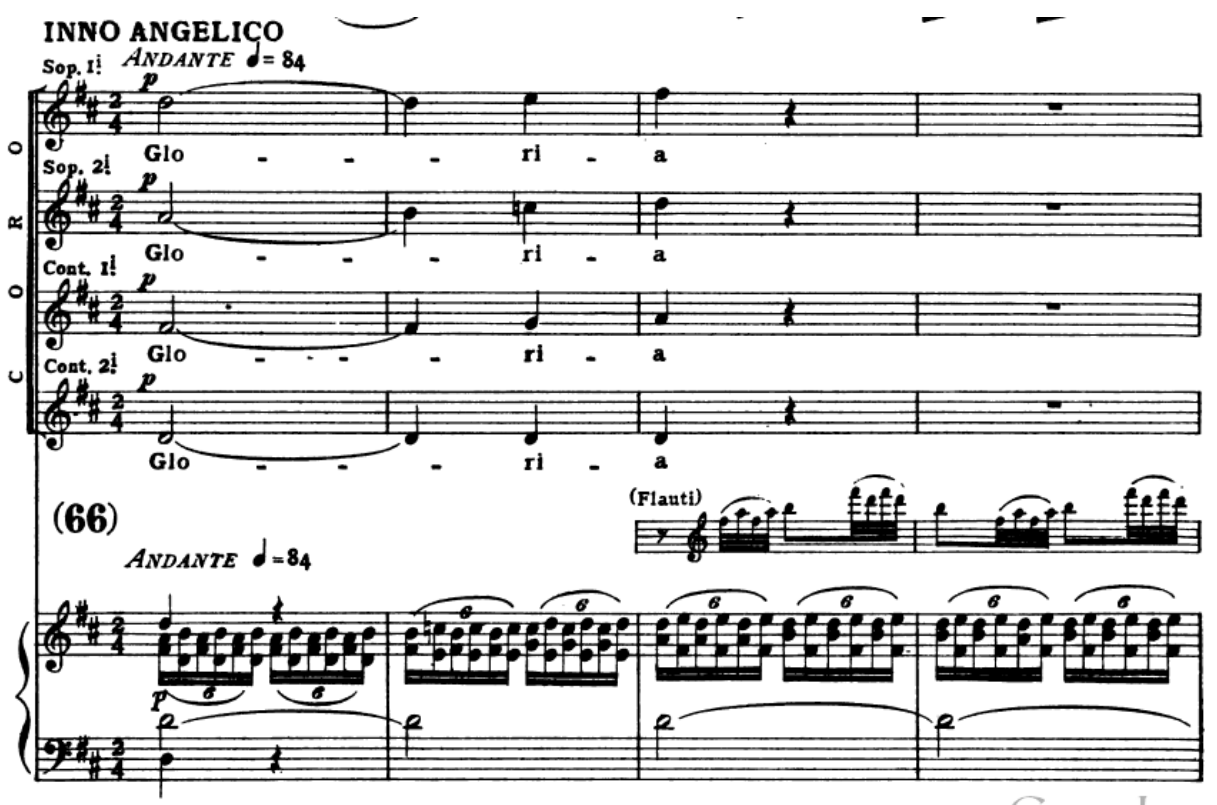




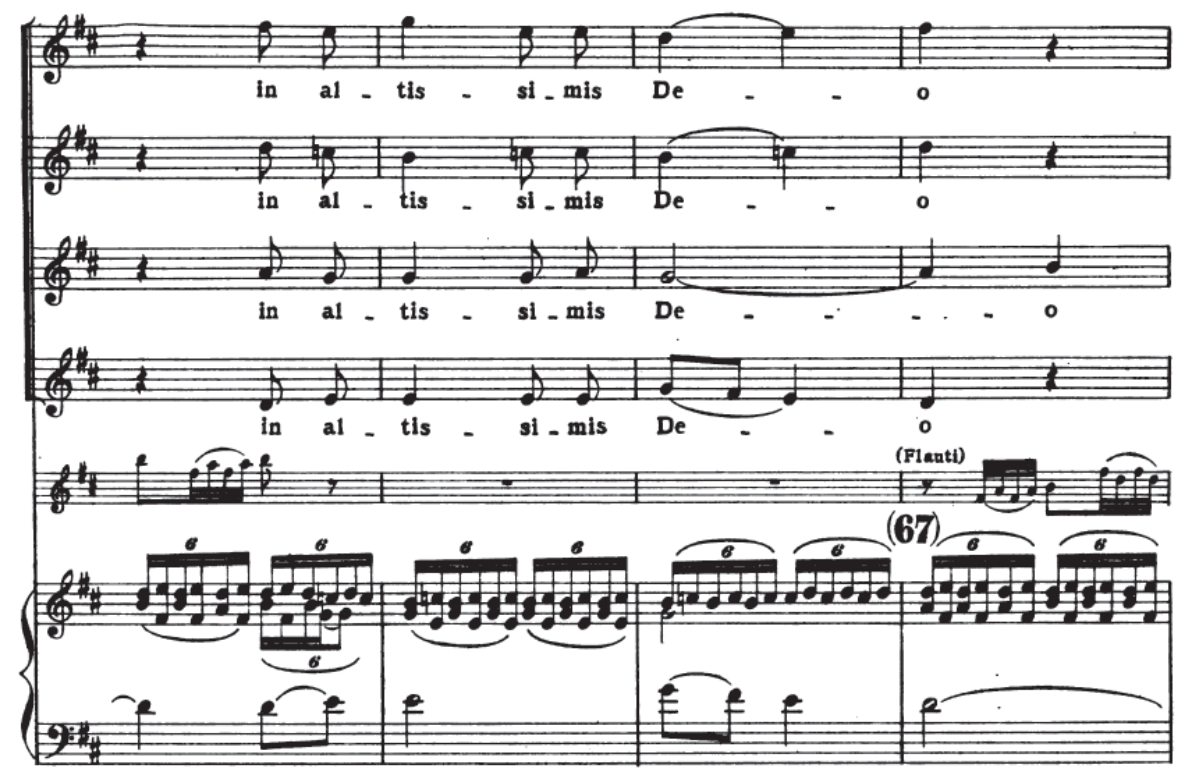

Exemplo 18: Perosi, Il Natale del Redentore, “Inno Angelico"; FONTE: Perosi (1899)

Além das tópicas pastorais e dos elementos representativos, há ainda na obra Em Bethleem, uma peça em que as categorias de intertextualidade estão claramente presentes: a "Cantilena". Trata-se de um momento na peça teatral em que Nossa Senhora acalenta o Menino Jesus, sendo a música de Nepomuceno, portanto, uma canção de ninar, para voz feminina (mezzo-soprano) e orquestra, com estrutura formal binária de canção. A orquestra executa um acompanhamento que segue o mesmo padrão rítmico e harmônico ao longo de toda a peça (Ex. 19). Entre a primeira e a segunda seção (c. 18-21) e ao final da segunda (c. 38-41) há um trecho instrumental, na qual se passa de Fá menor (tônica) para a homônima maior e que se caracteriza melodicamente por uma linha ascendente nas madeiras (Ex. 20).

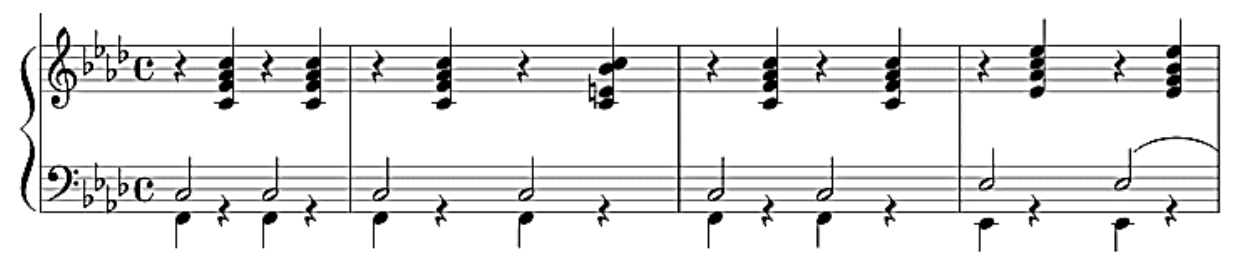

Exemplo 19: Nepomuceno, “Cantilena” de Em Bethleem, c. 1-4; FONTE: O autor (2020) 


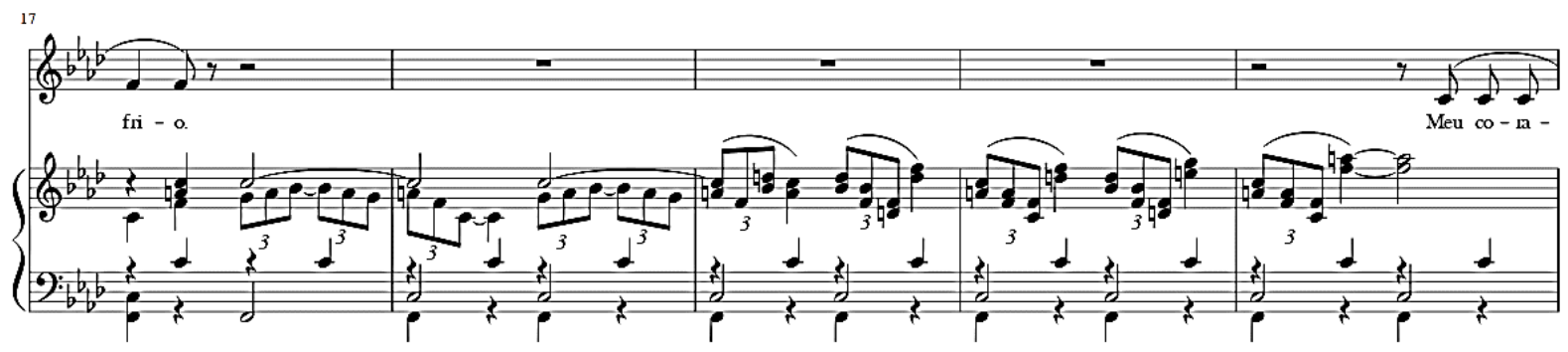

Exemplo 20: Nepomuceno, "Cantilena" de Em Bethleem, c. 17-21; FONTE: O autor (2020)

A linha vocal estrutura-se em quatro frases de quatro compassos com uma condução harmônica bem definida, ordenada segundo o esquema AA-BB: (1) compassos 2 a 5 (tônica-dominante), (2) compassos 6 a 9 (tônica-mediante [relativa maior]), (3) compassos 10 a 13 (supertônica-dominante) e (4) compassos 14 a 17 (supertônica-tônica) (Ex. 21 a 24).

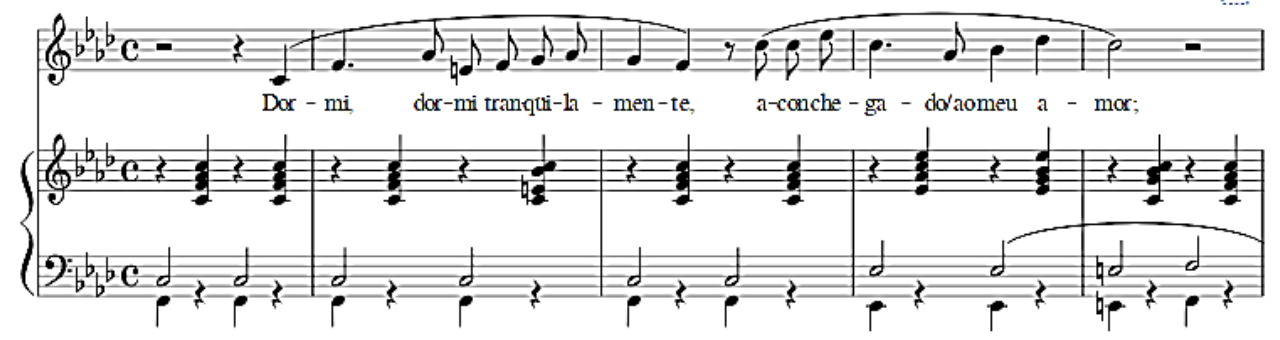

Exemplo 21: Nepomuceno, “Cantilena” de Em Bethleem, c. 1-5; FONTE: O autor (2020)

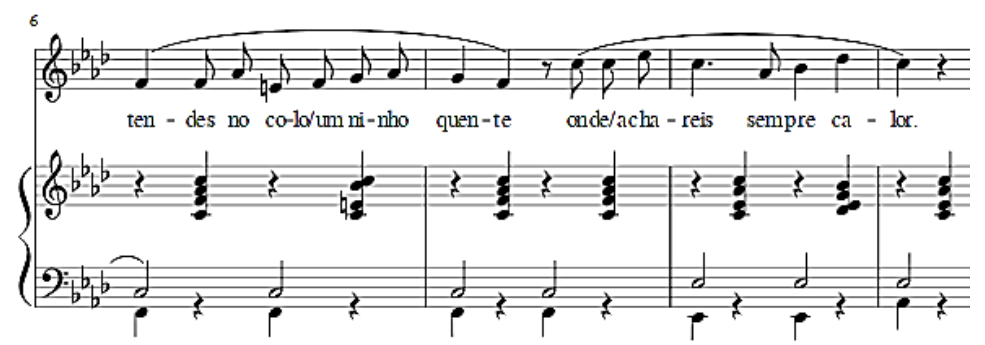

Exemplo 22: Nepomuceno, "Cantilena" de Em Bethleem, c. 6-9; FONTE: O autor (2020)

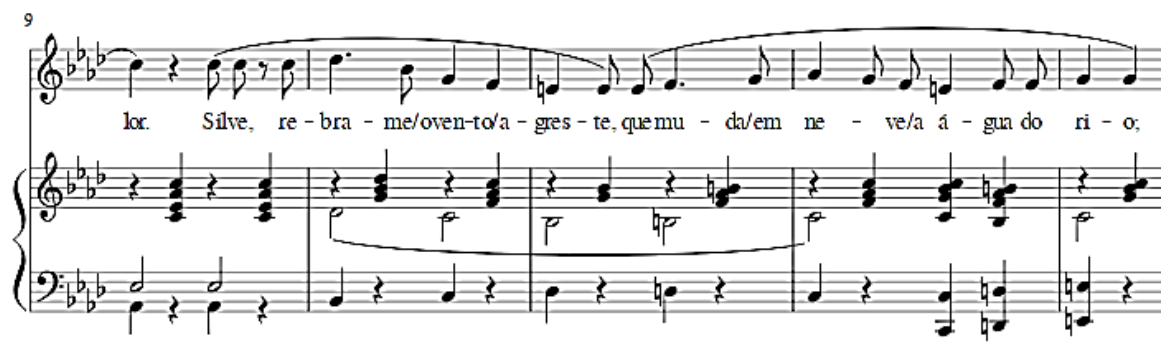

Exemplo 23: Nepomuceno, “Cantilena” de Em Bethleem, c. 9-13; FONTE: O autor (2020) 


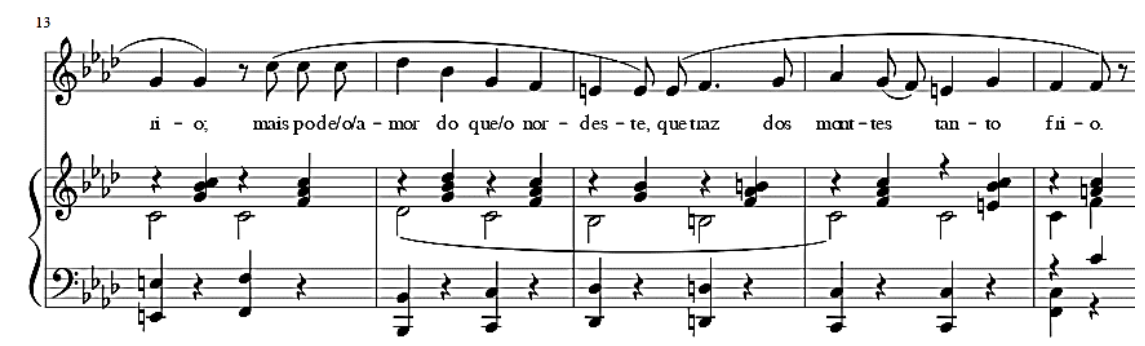

Exemplo 24: Nepomuceno, "Cantilena" de Em Bethleem, c. 13-17; FONTE: O autor (2020)

Nessa "Cantilena" de Nepomuceno foram identificadas relações de intertextualidade musical em relação à "Canção de Solveig" (Ex. 25 a 29) de E. Grieg (1843-1907), o que se evidenciou tanto pelo mesmo gênero musical a que pertencem, como também pelo esquema formal e pelos elementos melódicoharmônicos na linha melódica vocal e no acompanhamento orquestral.

Em primeiro lugar, há a intertextualidade quanto ao gênero musical. A "Canção de Solveig" foi composta como música incidental, como acompanhamento de uma obra teatral, Peer Gynt, de Henrik Ibsen (1828-1906), ${ }^{1}$ tendo como letra o trecho em que a personagem feminina principal, Solveig, canta para seu amado, Peer, expressando sua esperança em reencontrá-lo. Há, pois, um paralelo quanto ao contexto literário explorado em ambas as canções, pois Nepomuceno não apenas destina sua composição a uma obra teatral ("Pastoral", de Coelho Netto), como especificamente emprega como letra o trecho em que a personagem feminina principal, Maria Santíssima, canta para acalentar o Menino Jesus.

Em segundo lugar, quanto à forma musical, ambas as canções seguem um mesmo padrão. A “Canção de Solveig" estrutura-se segundo o esquema binário de canção (repetição de um mesmo período musical) e após cada período há um trecho musical de caráter contrastante, sobretudo harmônica e ritmicamente (mudança para 3/4, homônima maior, acordes dominante-tônica), com simples vocalize e acompanhamento orquestral (Ex. 29). Trata-se da mesma estrutura da

\footnotetext{
${ }^{1}$ Em 1867 o dramaturgo norueguês H. Ibsen (1828-1906) publicou um poema dramático em cinco atos chamada Peer Gynt. A obra veio a ser interpretada pela primeira vez em Oslo (antiga Christiania) e em 1876 com música incidental composta por E. Grieg (1843-1907). Dentre as vinte e três peças compostas para a apresentação cênica, o compositor selecionou entre 1888 e 1891 oito delas e as organizou em duas suítes orquestrais. Uma destas peças, pertencente ao Ato IV da música incidental, e posteriormente colocada como obra puramente instrumental na Suíte II op. 55, é a referida canção (Grout; Palisca 2007, p. 675; Csampai; Holland 1995, p. 454-455).
} 
peça de Nepomuceno, ainda que este opte por um trecho puramente instrumental (tercinas, homônima maior, acordes subdominante-tônica, madeiras), sem o vocalize de Grieg (Ex. 20). Em ambas as peças também se encontra o mesmo esquema formal para organização das quatro frases musicais de cada seção: $\mathrm{A}-\mathrm{A}^{\prime}-\mathrm{B}-\mathrm{B}^{\prime}$.

Em terceiro lugar, quanto à textura musical e quanto a elementos melódico-harmônicos há intensa semelhança entre as duas peças. Ambos os compositores optam por um tipo de escrita orquestral com função claramente de acompanhamento à linha vocal e imprimem uma regularidade a ele: um baixo a modo de bordão (quintas harmônicas) nos tempos fortes e acordes completos nos tempos fracos. As duas peças têm seus respectivos temas iniciais construídos a partir de uma linha melódica sobre as notas da tríade menor, padrão este comumente associado a um caráter emotivo de aceitação da dor, o que denota uma proximidade entre ambas as peças quanto à finalidade expressiva e ao tema tratado (Cf. Cooke 1973, p. 124-125).

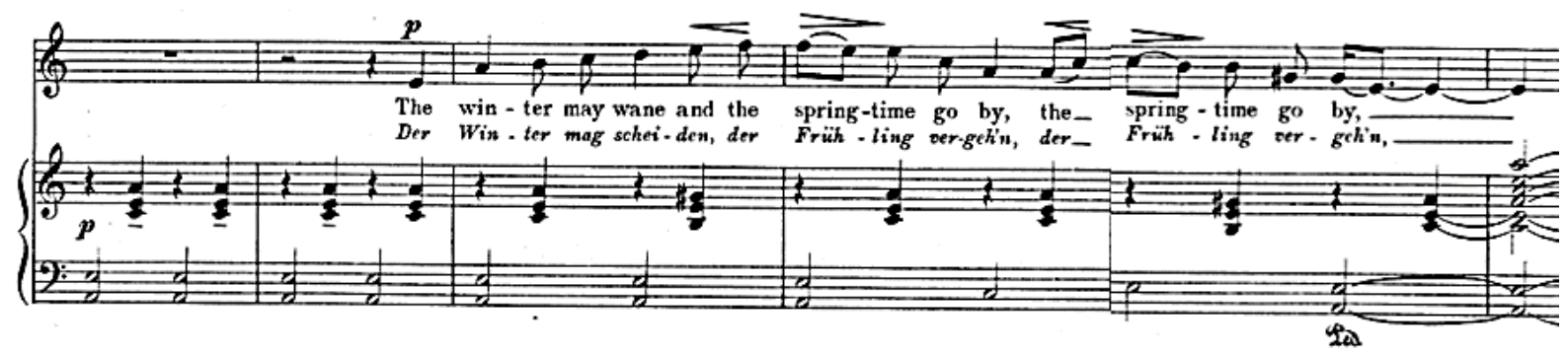

Exemplo 25: Grieg, “Canção de Solveig”, c. 8-12; FONTE: Grieg (1908)

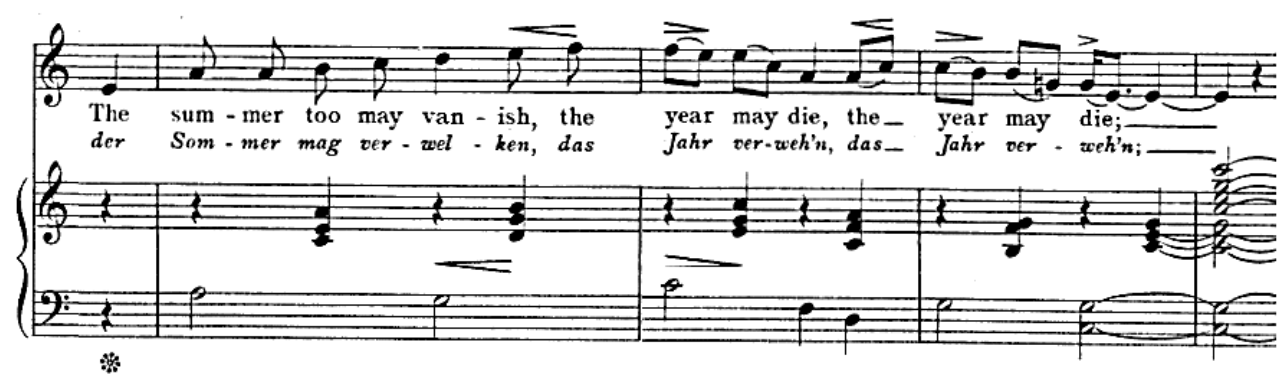

Exemplo 26: Grieg, “Canção de Solveig”, c. 14-17; FONTE: Grieg (1908) 
MUSICA THEORICA Revista da Associação Brasileira de Teoria e Análise Musical 2020, v. 5, n. 1, p. 196-241 - Journal of the Brazilian Society for Music

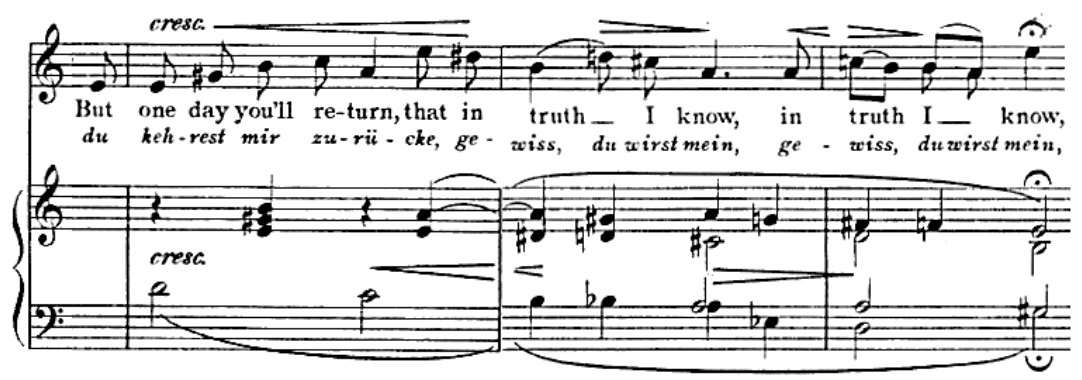

Exemplo 27: Grieg, “Canção de Solveig”, c. 18-20; FONTE: Grieg (1908)

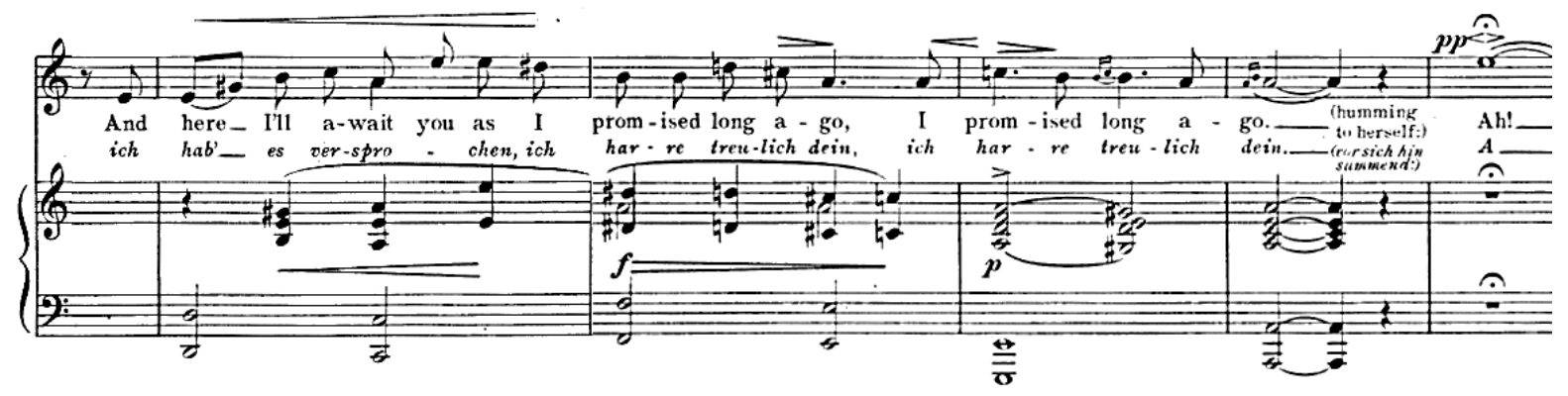

Exemplo 28: Grieg, “Canção de Solveig”, c. 26-39; FONTE: Grieg (1908)
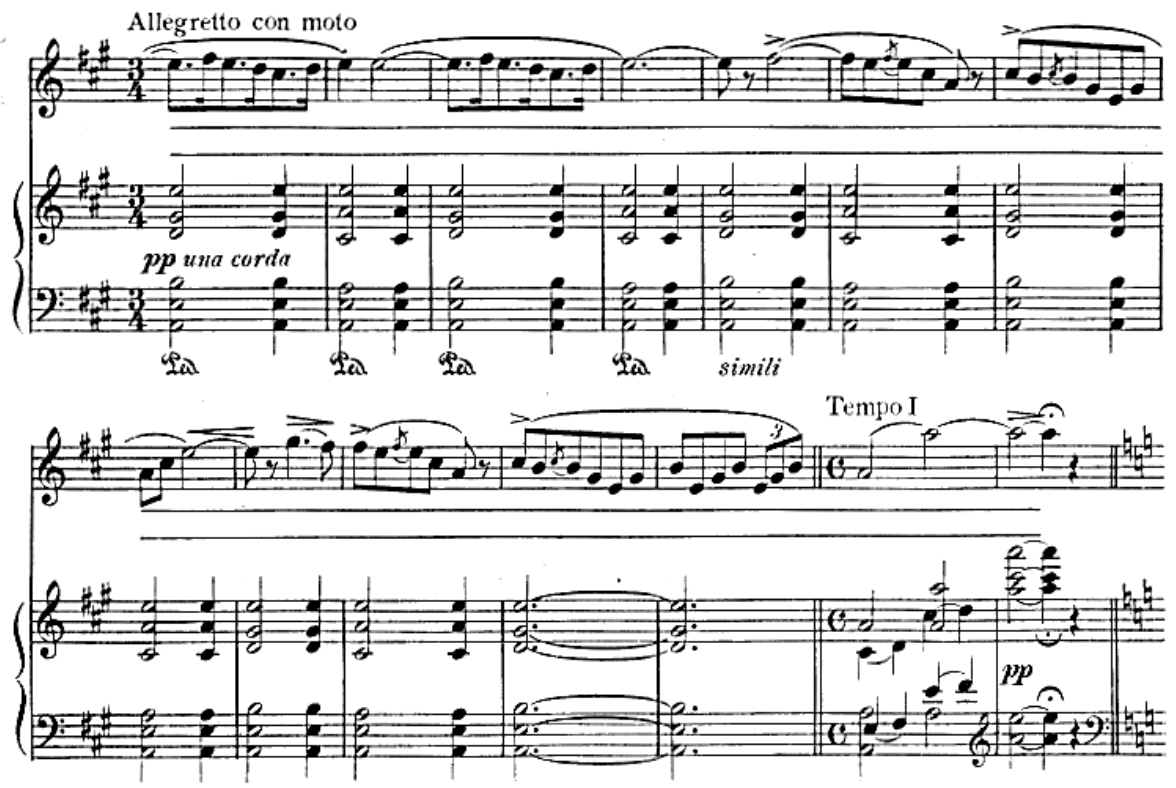

Exemplo 29: Grieg, "Canção de Solveig”, c. 26-39; FONTE: Grieg (1908)

Portanto, na "Cantilena" de Nepomuceno encontram-se relações de intertextualidade musical nos três níveis estruturais: no nível macro-musical (estrutura geral da canção e relação com a estrutura do texto), no nível médiomusical (concatenação das frases e relações de semelhança e contraste entre as 
diferentes seções internas) e no nível micromusical (utilização de motivos semelhantes para caracterização temática e para a escrita orquestral).

\section{A Missa perosiana}

Entre as obras sacras e religiosas de Alberto Nepomuceno, aquela em que se encontra mais presente a intertextualidade musical é a sua Missa a duas vozes. A análise dela indicou que se trata praticamente de uma paráfrase formal da Missa Te Deum laudamus de Lorenzo Perosi ${ }^{2}$ e que, além disso, também apresenta relações intertextuais em nível temático com a mesma citada obra ("Sanctus", "Gloria") e com cantos gregorianos ("Kyrie”, "Agnus Dei").

A "Missa" de Nepomuceno, em sua edição pela Bevilacqua \& C., apresenta o seguinte título oficial: "Missa duabus vocibus aequalibus quam in honorem Virginis Immaculatae concinnavit et Eminentissimo Domino Cardinali Arcoverde dicavit. Die 26 Octobris Anni 1915. A. Nepomucenus" [Missa a duas vozes iguais composta em honra da Virgem Imaculada e dedicada ao Sr. Eminentíssimo Cardeal Arcoverde. Dia 26 de outubro de 1915. A. Nepomuceno]. A referida data de 26 de outubro de 1915 marcou o jubileu episcopal (aniversário de vinte e cinco anos da sagração episcopal), de Dom Joaquim Arcoverde, então arcebispo do Rio de Janeiro e nessa data o próprio cardeal celebrou uma solene missa pontifical na Catedral Metropolitana do Rio de Janeiro, com a assistência de bispos e arcebispos de todo o Brasil. Executou-se, então, a Missa a duas vozes de Nepomuceno, o que ficou a cargo da Schola Cantorum Santa Cecília,

\footnotetext{
2 Perosi nasceu em Tortona, na Itália, em 1872 e morreu em Roma, em 1956. Iniciou seus estudos musicais com seu pai, Giuseppe Perosi (1849-1908), que era Maestro di Cappela da Catedral de Tortona. Estudou com Michele Saladino no Conservatório de Milão, onde diplomou-se em 1892. Após seus estudos em Milão, passou um ano de estudo na Kirchenmusikschule, em Regensburg, na Alemanha, com Franz Xaver Haberl, grande musicólogo, pioneiro editor das obras de Palestrina e Lassus. Em seguida, assumiu o trabalho de professor e diretor de música sacra em Imola, na Itália, entre 1892 e 1894, ano em que visitou a famosa Abadia de Solesmes, na França, onde estudou canto gregoriano com Dom Mocquereau e Dom Pothier. Entre 1894 e 1907, Perosi assumiu o cargo de Maestro da Capella Marciana na Basílica de São Marcos em Veneza, cujo então Patriarca era Dom Giuseppe Sarto, futuro Papa São Pio X, com quem Perosi cultivou grande amizade e por quem foi ordenado Sacerdote em 1895. Em 1898, Perosi foi indicado para o posto de Maestro Perpetuo della Capela Sistina, no Vaticano, cargo que manteve, ainda que com algumas interrupções, até sua morte, em 1956. Particularmente famoso por seus Oratórios, Perosi também compôs várias Missas e obras sacras menores, além de música secular, como, por exemplo, concertos e peças para música de câmara (Ciampa 2006, p. 41-151).
} 
MUSICA THEORICA Revista da Associação Brasileira de Teoria e Análise Musical 2020,

v. 5, n. 1, p. 196-241 - Journal of the Brazilian Society for Music

Theory and Analysis @ TeMA 2020 - ISSN 2525-5541

conduzida pelo Pe. José Alpheu Lopes de Araújo, conhecido pelo seu trabalho de qualificação da música sacra no Rio de Janeiro.

O formato que Nepomuceno utiliza, o de missa a duas vozes com acompanhamento de órgão, é um modelo bastante comum dentro do repertório produzido pelos compositores ligados ao Cecilianismo. ${ }^{3}$ Algumas regras, particularmente no sentido de afastar da igreja o caráter de música teatral, tornaram-se amplamente seguidas na produção de música sacra e são igualmente verificadas na Missa de Nepomuceno. Alguns exemplos são a eliminação de árias para cantores solistas, o predomínio da escrita coral, a alternância entre texturas imitativa e homofônica, a importância dada à inteligibilidade do texto, a referência a modelos musicais do passado (cantochão e polifonia de G. P. Palestrina) e a determinação da forma musical em função da estrutura do texto litúrgico.

Além desses princípios gerais, há também alguns esquemas formais para cada unidade do Ordinário da Missa que eram compartilhados pelos compositores que de alguma forma vinculavam-se ao Cecilianismo. Tais esquemas formais são detalhados por Giulio Bas (1874-1929) em seu célebre tratado de forma musical, editado entre 1920-1922, tendo ele próprio também atuado diretamente no movimento de restauração da música sacra católica no início do século XX. Em suma, a forma musical seguida na Missa católica era a seguinte, conforme formulada por Bas:

"Kyrie". Divisão A-B-A ou A-B-C, sendo a distinção das partes não fundamentada apenas na caracterização temática, mas sim em relações tonais e a segunda seção geralmente assumindo um caráter contrastante em relação ao

\footnotetext{
${ }^{3} \mathrm{O}$ cecilianismo configura-se como um dialeto estilístico, dentro do qual, mesmo com eventuais diferenças quanto à apropriação ou negação de procedimentos compositivos da música de concerto que lhe foi contemporânea, havia certa convenção quanto a alguns caracteres. Na melodia, linhas vocais prevalentemente por graus conjuntos, sem ornamentação e sem grandes saltos, evitando-se manifestações de virtuosismo. No ritmo, tendência à uniformização e regularidade. Na harmonia, alternância entre tonalismo e modalismo, este utilizado em sentido historicista. Na textura, prevalência de escrita coral homofônica, com uso limitado de trechos imitativos ou de solos vocais, predominando conjuntos vocais mais simples (uma, duas ou três vozes) que a antiga polifonia palestriniana, sendo comum igualmente o acompanhamento de órgão ou harmônio. Na forma, subordinação da organização musical às exigências dos textos litúrgicos oficiais da Igreja, prevalecendo opção por caracterização das diferentes seções por meio de variações de textura (homofonia/contraponto, solo/tutti etc.), de andamento e de fórmulas de compassos.
} 
primeiro e ao último (por meio de tonalidade ou pela alternância de texturas: solo/coro, imitação/homofonia etc.) (Bas 1957, p. 148).

"Gloria". Divisão dos versículos em quatro seções distintas. A primeira (A), do início até "Glorificamus te"; a segunda (B), de "Gratias agimus até Filius Patris"; a terceira (C), de "Qui tollis peccata mundi" até "Qui sedes ad dexteram Patris"; e a quarta $\left(\mathrm{A}^{\prime}\right)$, enfim, a partir de "Quoniam tu solus sanctus" até o final (Bas 1957, p. 149). A parte A é composta de dois períodos, um fechado (tonal) e um modulante; a parte B é composta de quatro períodos contrastantes entre si; a parte C é composta de três períodos dispostos de forma orgânica; a parte final é composta de dois períodos, um modulante e outro, temático e tonal (Bas 1957, p. 149-150).

"Credo": divisão tríplice em grandes seções, cada uma das quais iniciando-se com um versículo característico, na tonalidade principal, e compreendendo 5 versículos, agrupados 2+3 e 3+2 (Bas 1957, p. 146).

"Sanctus-Benedictus": divisão segundo a forma tradicional de responsório, modelo A-B-A', em que após uma primeira parte (o "corpo do responsório") sucede-se outra (o "versículo") e, em seguida, retorna-se à primeira parte, não repetida inteiramente, mas apenas em sua última frase (a "frase de repetição") (Bas 1957, p. 129-133).

"Agnus Dei": divisão semelhante ao "Kyrie", geralmente um desenvolvimento ou adaptação do material dele (Bas 1957, p. 153).

Ainda que se trate, portanto, de padrões formais utilizados por vários compositores, pode-se dizer que a Missa de Nepomuceno tem como modelo específico a Missa Te Deum laudamus de Perosi, uma obra, inclusive, bastante executada e conhecida no Brasil na época (Cf. Teixeira 2016). Isso se justifica pelo modo concreto com que se trabalham as articulações das texturas musicais, pelo papel funcional atribuído ao tema instrumental introdutório e por algumas citações temáticas.

Nepomuceno elabora uma introdução para sua Missa por meio de um solo de órgão com um perfil melódico que remete diretamente a padrões encontrados no repertório do canto gregoriano (Modo I - Ré-Lá-Si b-Lá) (Ex. 30 e 31). Este mesmo tema é utilizado nas demais peças da Missa, seja como prelúdio, interlúdio ou póslúdio e tal recorrência coincide com aquele empregado por Perosi na Missa Te Deum laudamus e também na Missa Prima Ponficalis, de 1897. Além disso, a configuração melódica que Nepomuceno emprega nessa 
MUSICA THEORICA Revista da Associação Brasileira de Teoria e Análise Musical 2020,

v. 5, n. 1, p. 196-241 - Journal of the Brazilian Society for Music

introdução instrumental remete diretamente ao tema inicial e final do moteto Ecce panis angelorum (1910), também de Perosi (Ex. 32).

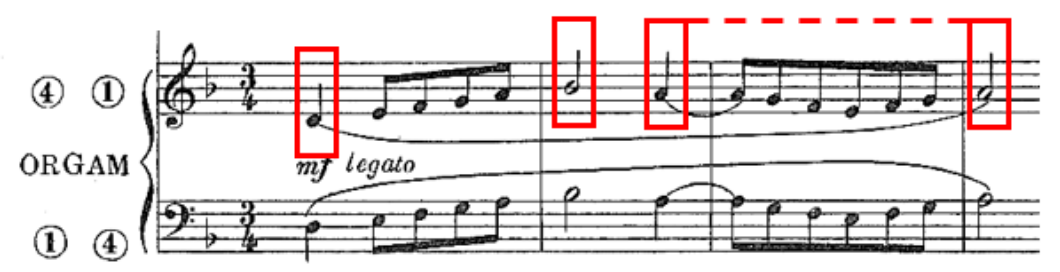

Exemplo 30: Nepomuceno, introdução instrumental na Missa; FONTE: O autor (2020)

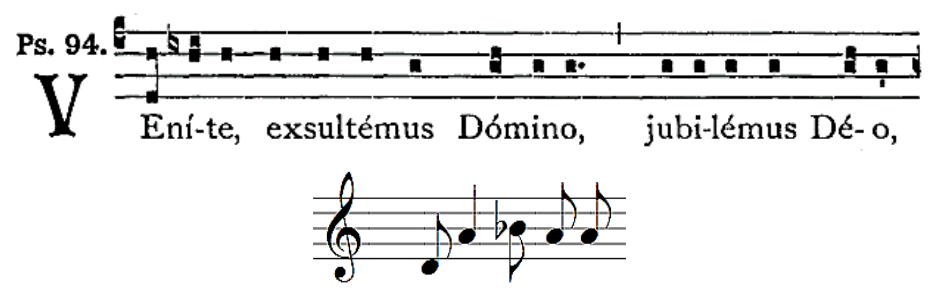

Exemplo 31: Exemplo de sequência Ré-Lá-Si -Lá no cantochão (Canto “Venite, exsultemus Domino"); FONTE: “Liber Usualis” (1961, p. 368)
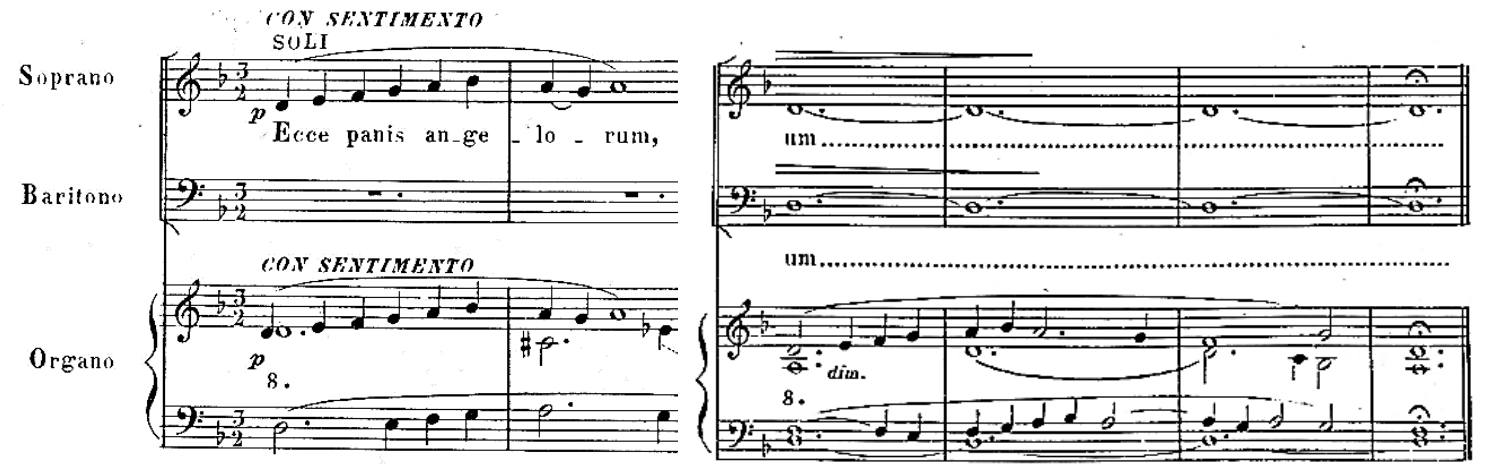

Exemplo 32: Perosi, tema inicial e final no moteto Ecce panis angelorum; FONTE: Perosi (1900)

Sob o aspecto temático, Nepomuceno faz ainda uso no "Kyrie" de uma típica figuração melódica gregoriana. Na primeira entrada do coro, após a introdução instrumental, tem-se o primeiro "Kyrie eleison" cantado pelas duas vozes em uníssono e em homofonia com o órgão (Ex. 33). Nesse pequeno trecho, a linha melódica aproxima-se estilisticamente do canto gregoriano, sendo possível apontar, inclusive, exemplar concreto de cantochão que segue a mesma forma melódica (descida melódica por grau conjunto no âmbito de uma $4^{a}$ justa 
seguida por um salto de $3^{3}$, sendo o salto então preenchido com grau conjuntos de forma ascendente) (Ex. 34). Além disso, encontra-se no tema inicial do "Kyrie" de Nepomuceno o inciso Fá-Sol-Lá-Lá, um motivo melódico antiquíssimo (Cf. Asensio 2016, p. 244-245) e que se encontra em vários “Kyries” gregorianos (Ex. 35). ${ }^{4}$ Trata-se, pois, de uma tipo de intertextualidade tanto de citação direta de material temático como também mais genérica, no âmbito estilístico.

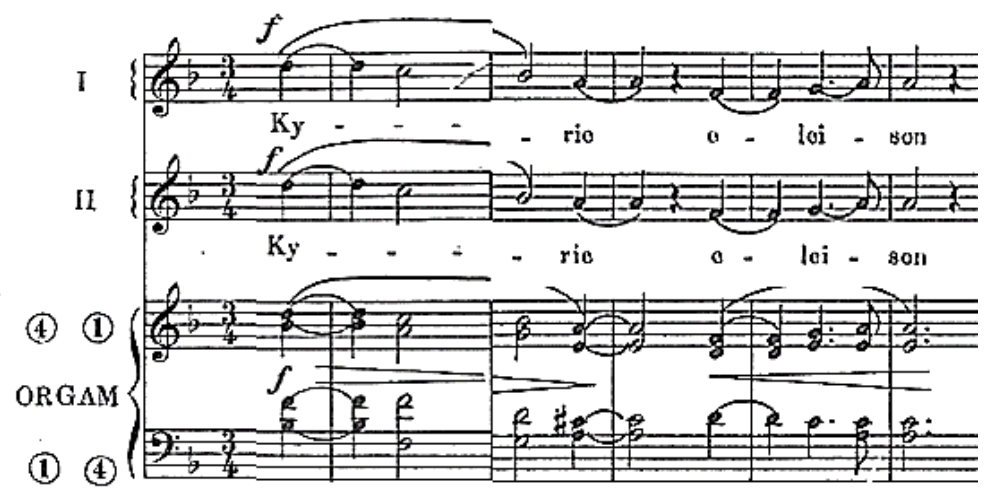

Exemplo 33: Nepomuceno, início do “Kyrie”; FONTE: Nepomuceno [1915b]
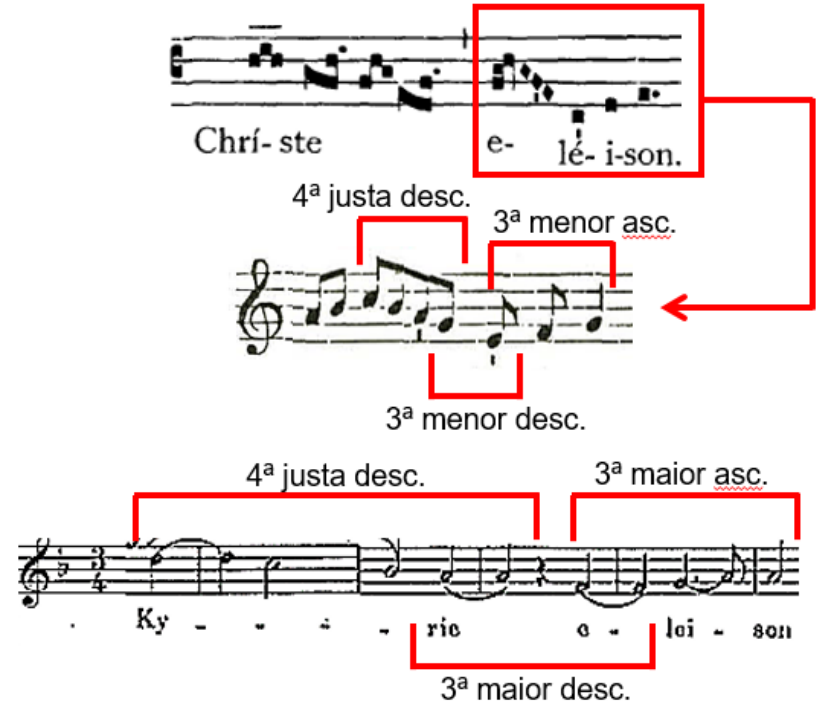

Exemplo 34: "Kyrie" de Nepomuceno e "Kyrie" I gregoriano; FONTE: Nepomuceno [1915b]; Liber Usualis (1961, p. 16)

\footnotetext{
${ }^{4}$ No Kyrie X do "Liber usualis" há as mesmas notas (Fá-Sol-Lá-Lá); nos Kyries XV, XVI e XVIII há o mesmo desenho melódico mas com as notas Sol-Lá-Si; enquanto que no Kyrie V utiliza-se as notas Mi-Fá-Sol, ou seja, com um semitom inicial
} 


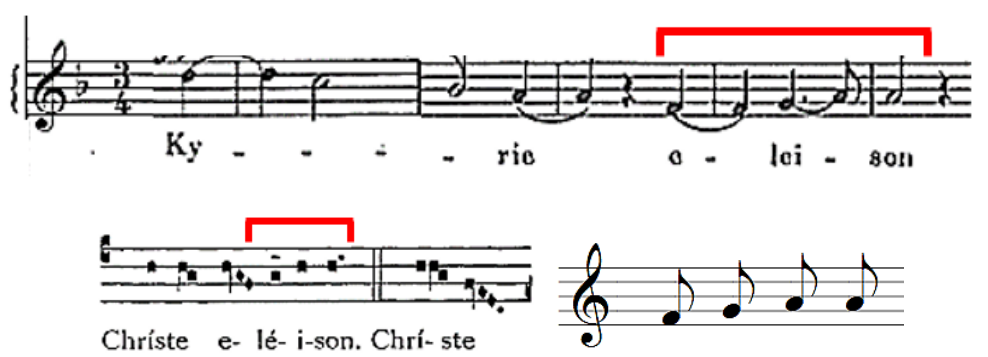

Exemplo 35: Nepomuceno, início do "Kyrie" e "Kyrie" X gregoriano; FONTE:

Nepomuceno [1915b]; “Liber Usualis” (1961, p. 43)

Encontra-se também uma apropriação estilística de melodia gregoriana no "Agnus Dei" da Missa de Nepomuceno. O terceiro "Agnus Dei" apresenta uma frase melódica cujo perfil se atém unicamente ao âmbito de três notas contíguas, Sol, Lá e Si b, trazendo reminiscências de arcaicos exemplares de "Agnus Dei" gregorianos, tais como o XVIII da Edição Vaticana (Ex. 36 e 37).

Quanto ao modelo formal, o "Agnus Dei" segue a mesma estrutura do "Agnus Dei" da Missa Te Deum laudamus de Perosi: introdução instrumental com solo de órgão (do início da Missa), "Agnus Dei" 1 e 2 com a mesma ou quase idêntica frase melódica, alternância entre solistas das vozes 1 e 2 em "miserere nobis", solo de órgão como interlúdio após o "Agnus Dei" 2, "Agnus Dei" 2 em uníssono, "dona nobis pacem" final em textura contrapontística.

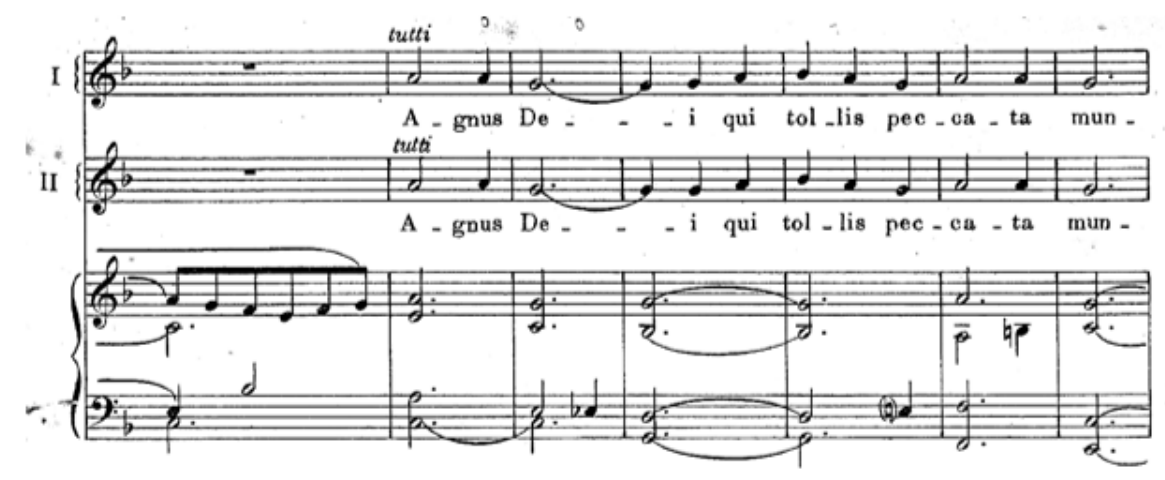

Exemplo 36: Nepomuceno, “Agnus Dei”, FONTE: Nepomuceno [1915b]
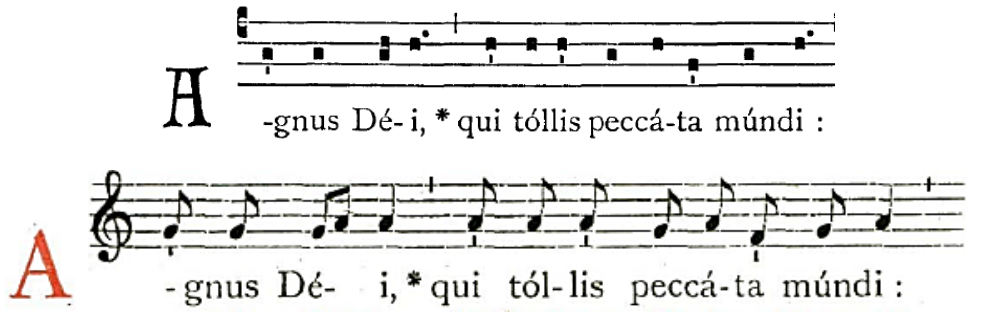

Exemplo 37: “Agnus Dei” gregoriano XVIII; FONTE: “Liber Usualis” (1961, p. 63) 
No "Gloria" de Nepomuceno, por sua vez, encontramos dois tipos de intertextualidade musical em relação à Missa Te Deum laudamus de Perosi. A primeira é no nível formal, uma citação de esquema formal, o que se baseia em três fatos: (1) no emprego em ambas as peças do tema introdutório com solo de órgão do "Kyrie" como início também do "Gloria"; (2) na alternância de andamentos e de fórmulas de compasso ocorrendo da mesma maneira em ambas as peças; e (3) nas mudanças de textura musical ("tutti" para solo, homofonia para imitação etc.), ocorrendo praticamente nos mesmos pontos do texto litúrgico.

O segundo tipo de intertextualidade no "Gloria" ocorre em nível temático no verso "Domine Deus, agnus Dei, Filius Patris" (Ex. 38). Trata-se de uma estrutura fraseológica binária, com a primeira parte em escrita imitativa a partir do motivo melódico Lá-Ré na Voz 1 e a repetição/resposta na Voz 2 em "Domine Deus". Na sequência, em "Agnus Dei", compasso 60, há nova frase de caráter contrapontístico e encerra-se com "Filius Patris" em estrito uníssono das duas vozes. Harmonicamente, tem-se o trecho iniciando-se em Ré menor, tonicização na relativa maior, Fá maior e encerramento na dominante, Lá maior. A mesma estrutura é encontrada no "Gloria" de Perosi: o mesmo motivo melódico (4 $4^{\underline{a}}$ ascendente $\mathrm{Si}-\mathrm{Mi}$ ) como pergunta-resposta entre as duas vozes em "Domine Deus", vozes defasadas em "Agnus Dei", "Filius Patris" em uníssono e, harmonicamente, um encaminhamento da tônica (Si menor) para a dominante (Ex. 39). Quanto ao perfil melódico, ambos os compositores empregam ascensão em "Filius", ponto culminante em "Patris" e cadencimento em linha descendente. Trata-se, pois, de uma verdadeira citação textual na Missa de Nepomuceno.

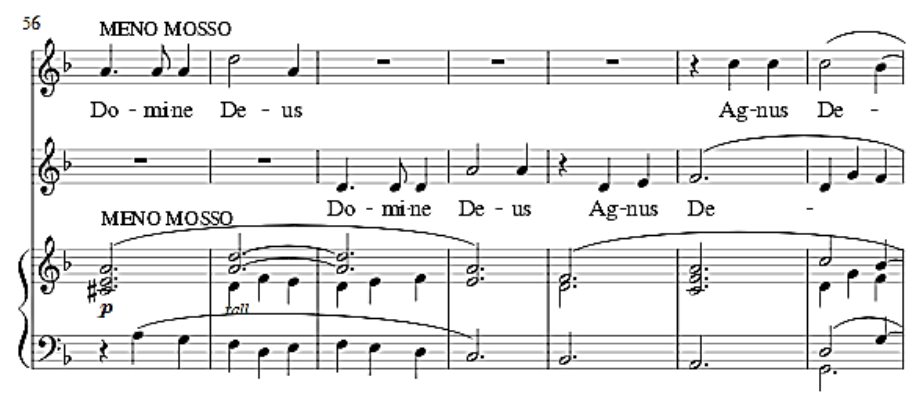


MUSICA THEORICA Revista da Associação Brasileira de Teoria e Análise Musical 2020, v. 5, n. 1, p. 196-241 - Journal of the Brazilian Society for Music

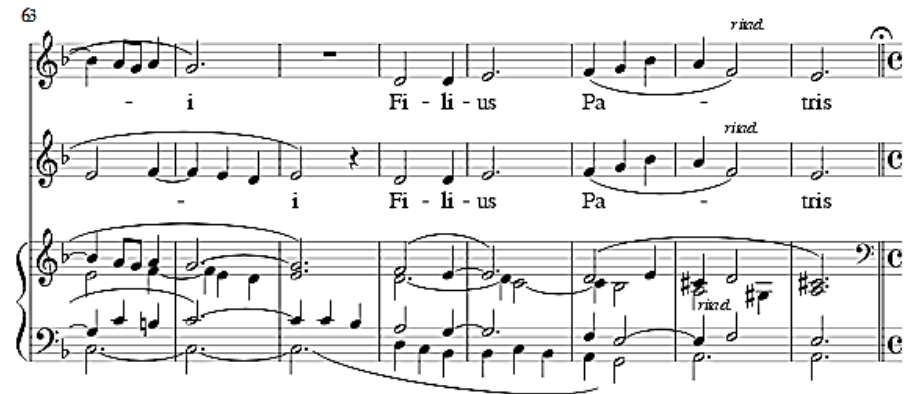

Exemplo 38: Nepomuceno, “Gloria” da Missa, c. 56-70; FONTE: O autor (2020)
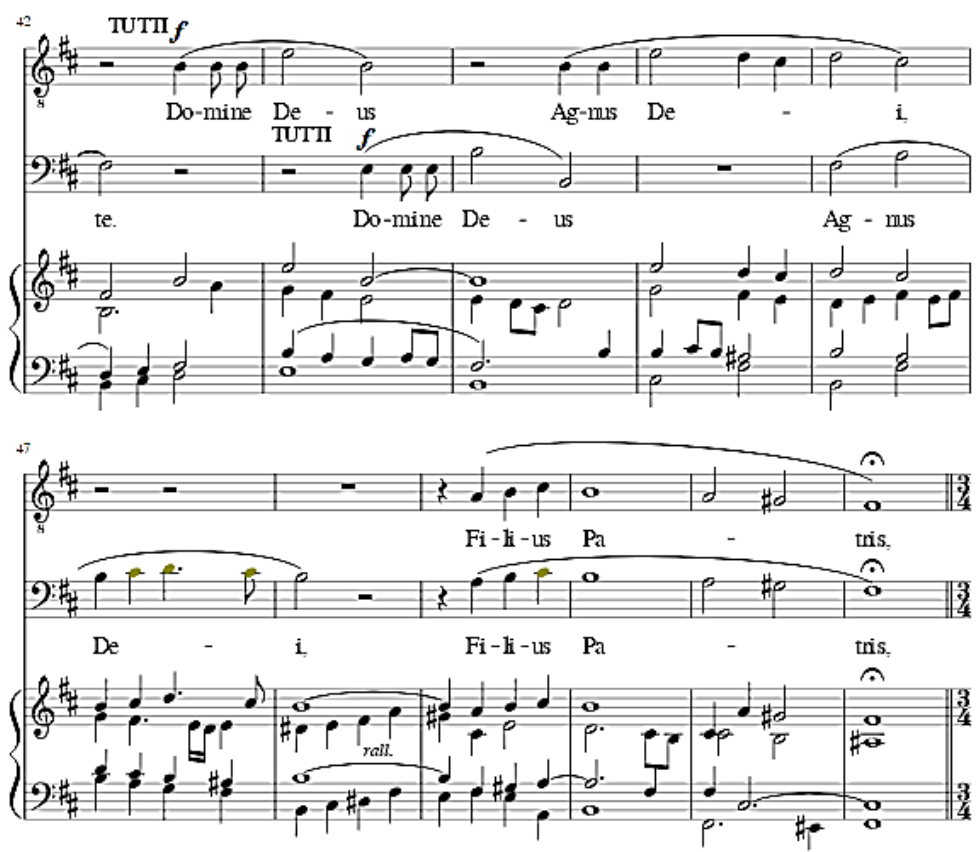

Exemplo 39: Perosi, “Gloria” da Missa Te Deum laudamus, c. 42-52; FONTE: Perosi $(1899 b)$

$\mathrm{O}$ "Credo" de Nepomuceno também segue o mesmo esquema formal do "Credo" da já mencionada Missa de Perosi. Destacamos entre as semelhanças entre as duas obras: a introdução com solo de órgão sendo empregada duas vezes, a tríplice divisão formal proposta por Bas sendo estritamente seguida e as alterações de métrica (fórmulas de compasso) ocorrendo exatamente no mesmo ponto estrutural, configurando pontos de articulação bem definidos.

Entretanto, é no "Sanctus" que se encontra a maior semelhança entre a Missa de Nepomuceno e a Te Deum laudamus de Perosi. Ambas as peças são idênticas no que se refere à divisão dos versos do texto litúrgico entre as vozes e à respectiva textura coral utilizada. Mas além dessa citação de esquema formal, é no "Sanctus" que mais se encontraram apropriações de desenhos melódicos e 
citações textuais. Consideramos, por isso mesmo, o "Sanctus" de Nepomuceno como uma paráfrase (uma citação reelaborada livremente) do "Sanctus" de Perosi. Como exemplos de citação textural destacamos o tema inicial, intercalado entre as duas vozes (Ex. 40 e 41), a configuração melódico-harmônica em "pleni sunt coeli et terra" (Ex. 42 e 43), a textura imitativa em "gloria tua" (Ex. 44 e 45) e a estrutura da frase ao final (Ex. 46 e 47).

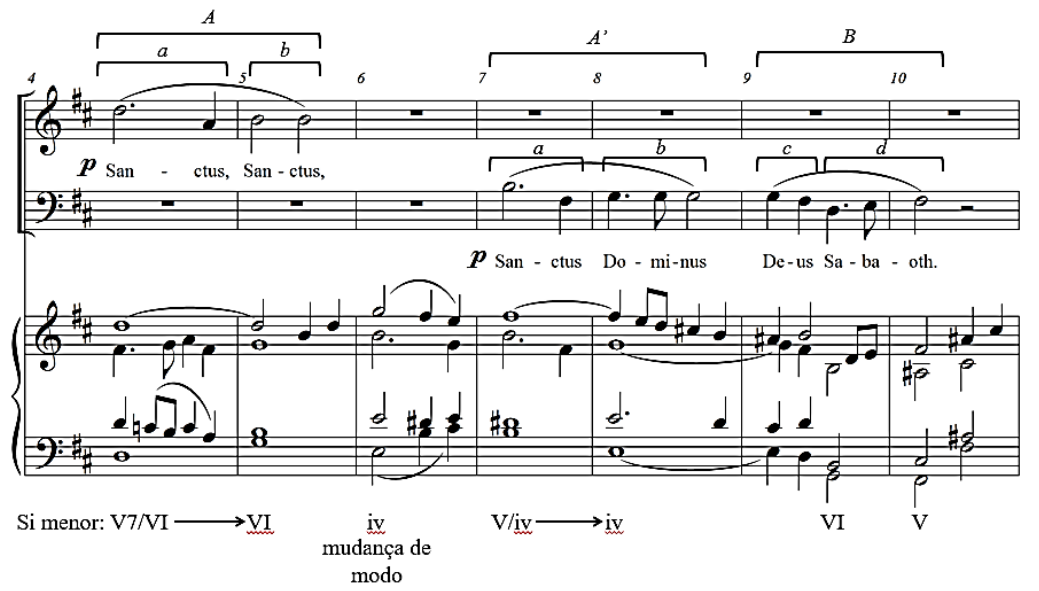

Exemplo 40: Perosi, "Sanctus" da Missa Te Deum laudamus, c. 4-10; FONTE: O autor (2020)

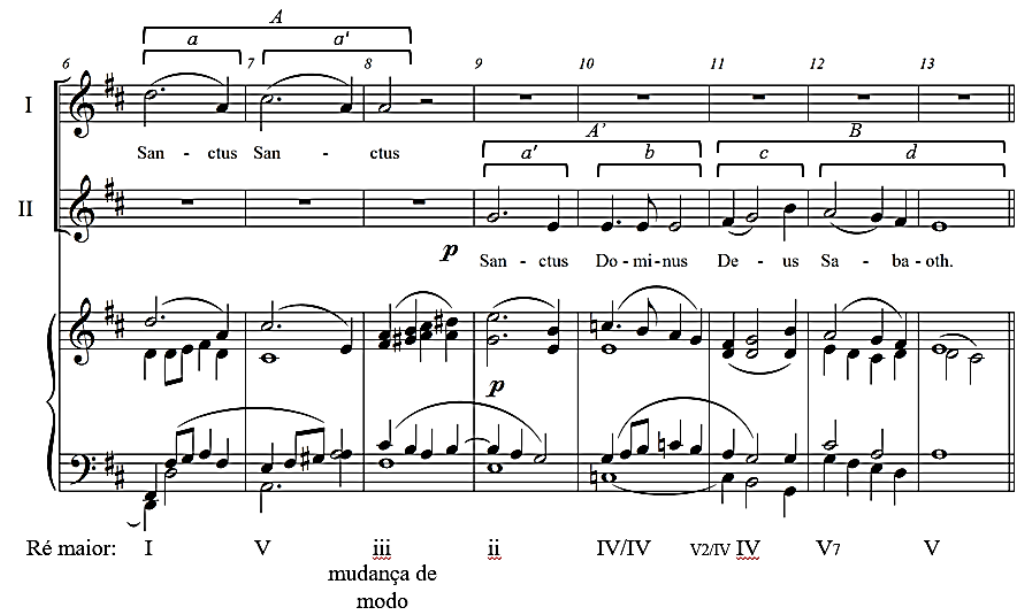

Exemplo 41: Nepomuceno, "Sanctus", c. 4-13; FONTE: O autor (2020) 
MUSICA THEORICA Revista da Associação Brasileira de Teoria e Análise Musical 2020, v. 5, n. 1, p. 196-241 - Journal of the Brazilian Society for Music Theory and Analysis @ TeMA 2020 - ISSN 2525-5541
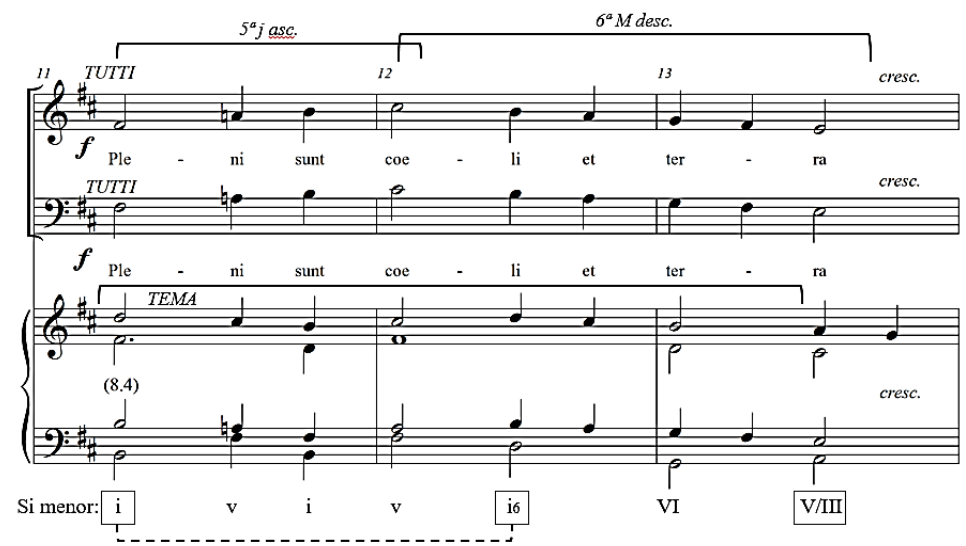

Exemplo 42: Perosi, "Sanctus" da Missa Te Deum laudamus, c. 11-13; FONTE: O autor (2020)

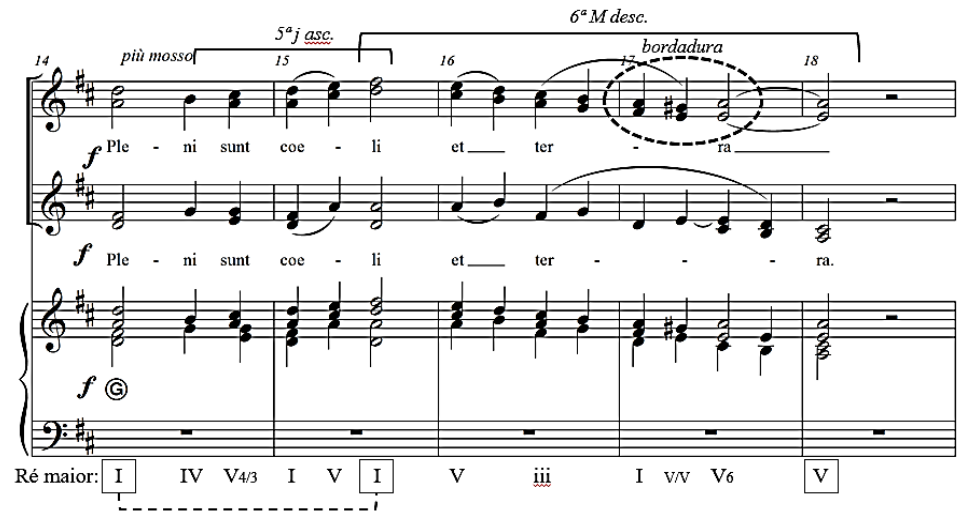

Exemplo 43: Nepomuceno, "Sanctus", c. 14-18; FONTE: O autor (2020)

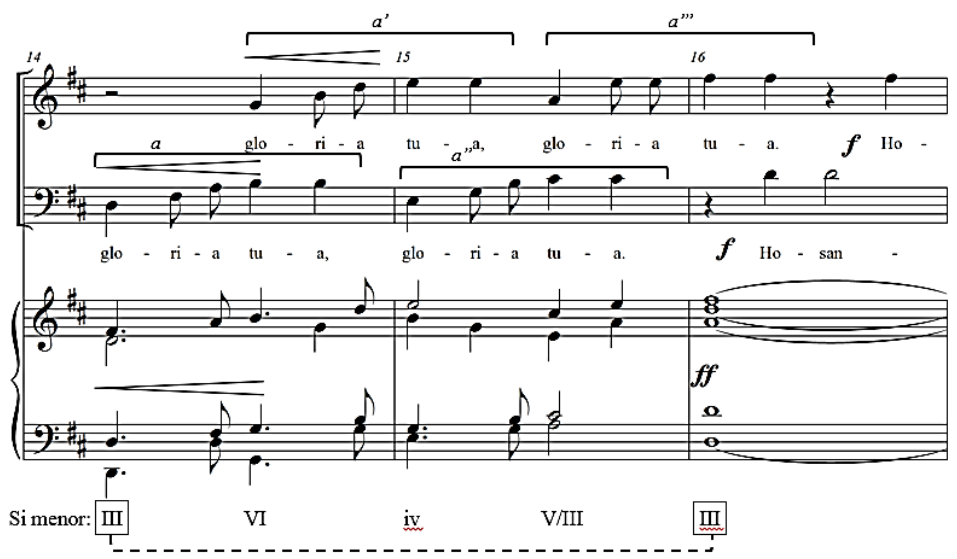

Exemplo 44: Perosi "Sanctus" da Missa Te Deum laudamus, c. 14-16; FONTE: O autor (2020) 


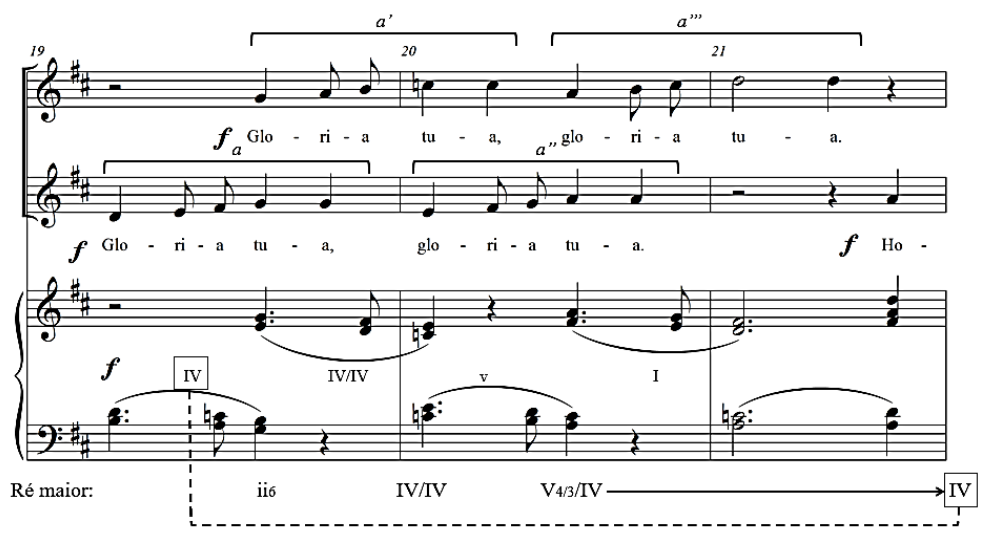

Exemplo 45: Nepomuceno, "Sanctus" da Missa, c. 19-21; FONTE: O autor (2020)

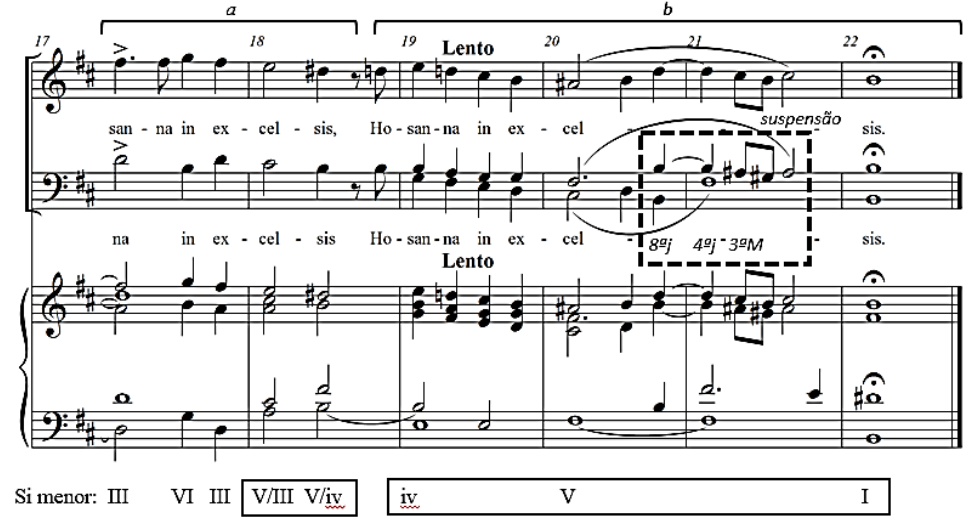

Exemplo 46: Perosi, "Sanctus" da Missa Te Deum laudamus, c. 17-22 (final); FONTE: $\mathrm{O}$ autor (2020)

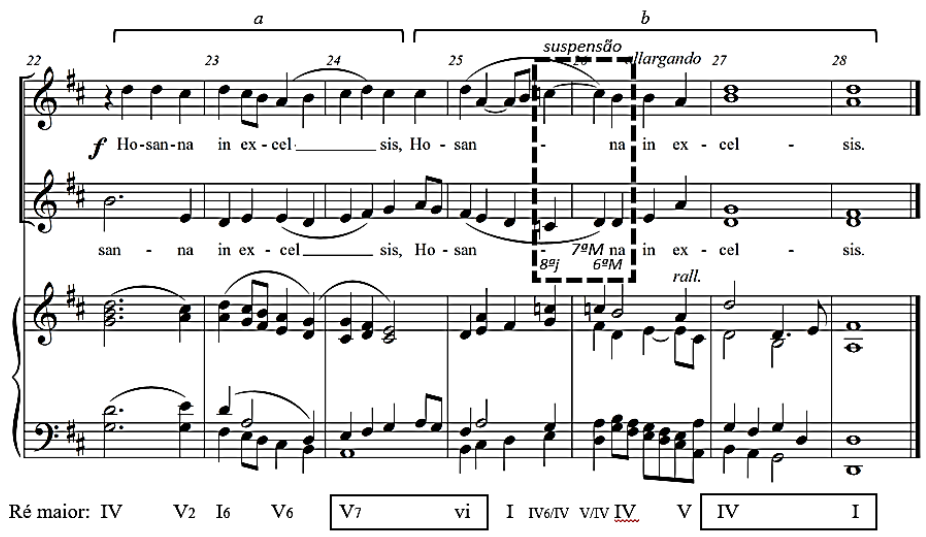

Exemplo 47: Nepomuceno, "Sanctus" da Missa, c. 22-28 (final); FONTE: O autor (2020) 
MUSICA THEORICA Revista da Associação Brasileira de Teoria e Análise Musical 2020,

v. 5, n. 1, p. 196-241 - Journal of the Brazilian Society for Music

Theory and Analysis @ TeMA 2020 - ISSN 2525-5541

\section{Conclusões}

A partir das análises feitas, sintetizamos na Tabela 3 as diferentes categorias de intertextualidade encontradas nas peças sacras e religiosas de Alberto Nepomuceno. Na peça para piano Cloches de Noël há citações estilísticas na micro-escala e na média-escala, além de uma citação textual com intenção referencial também nesse nível das frases e temas; e citação de materiais geradores na macro-escala. Na música incidental Em Bethleem há uso de tópicas pastorais e procedimentos de representação musical no "Prelúdio" e no "Coro dos Anjos", o que enquadramos como intertextualidade musical em macro-escala (indicamos $\operatorname{com}^{*}$ ), ainda que somente López-Cano considere o uso de tópicas como um tipo de intertextualidade. Também na mesma obra, há citações nos três níveis estruturais da "Cantilena". Finalmente, na "Missa a duas vozes" há citação de esquema formal na macro-escala, citação estilística e textual na média escala e citação estilística também na micro escala.

\begin{tabular}{|c|c|c|c|}
\hline & \multicolumn{3}{|c|}{ CATEGORIAS DE INTERTEXTUALIDADE MUSICAL } \\
\hline & MICRO ESCALA & MÉDIA ESCALA & MACRO ESCALA \\
\hline $\begin{array}{l}\text { Cloches de Noël } \\
\text { (Piano) }\end{array}$ & $\begin{array}{l}\begin{array}{l}\text { Citação estilística } \\
\text { (textura e timbre) }\end{array} \\
\text { Evocação da sonoridade } \\
\text { típica dos sinos de } \\
\text { igreja: acordes } \\
\text { consonantes regulares, } \\
\text { ostinato e diferentes } \\
\text { registros de altura. } \\
\text { Procedimento } \\
\text { empregado por Liszt } \\
\text { em obras para piano } \\
\text { com cunho religioso (ex: } \\
\text { “Angelus!” e } \\
\text { "Abendglocken"). } \\
\\
\text { Citação estilística } \\
\text { (Harmonia) } \\
\text { Harmonização da } \\
\text { melodia gregoriana ao } \\
\text { modo como alguns } \\
\text { tratadistas o entendiam } \\
\text { no final do século XIX } \\
\text { (utilização só de notas } \\
\text { da escala, acordes } \\
\text { correspondentes a cada } \\
\text { nota da melodia e } \\
\text { preferencialmente em }\end{array}$ & $\begin{array}{l}\text { Citação estilística } \\
\text { Utilização de linhas } \\
\text { melódicas que remetem } \\
\text { ao estilo do cantochão: } \\
\text { âmbito restrito (uma } \\
\text { sexta ou uma oitava), } \\
\text { predomínio de graus } \\
\text { conjuntos, saltos de } \\
\text { quarta ou quinta } \\
\text { seguidos por } \\
\text { movimento contrário } \\
\text { em grau conjunto, } \\
\text { ritmo regular em } \\
\text { andamento lento e } \\
\text { direcionamento não- } \\
\text { tonal das frases } \\
\text { (ausência de relação } \\
\text { sensível ou algum tipo } \\
\text { de cromatismo). } \\
\text { Citação textual com } \\
\text { intenção referencial } \\
\text { Transcrição literal (com } \\
\text { inserção da letra latina } \\
\text { original na partitura) } \\
\text { da melodia da antífona }\end{array}$ & $\begin{array}{l}\text { Citação de materiais } \\
\text { geradores } \\
\text { Estruturação segundo a } \\
\text { forma A-B1-A'-B2-A", } \\
\text { sendo B1 e B2 } \\
\text { diferentes trechos da } \\
\text { melodia gregoriana } \\
\text { "Hodie Christus natus } \\
\text { est" harmonizada. } \\
\text { Procedimento } \\
\text { empregado por Liszt } \\
\text { em obras para piano } \\
\text { com cunho religioso } \\
\text { (ex: Stabat Mater e } \\
\text { Vexilla Regis). }\end{array}$ \\
\hline
\end{tabular}




\begin{tabular}{|c|c|c|c|}
\hline & $\begin{array}{l}\text { posição fundamental, } \\
\text { etc.) Clara referência à } \\
\text { sonoridade harmônica } \\
\text { ouvida no } \\
\text { acompanhamento do } \\
\text { canto gregoriano } \\
\text { durante os ofícios } \\
\text { religiosos. }\end{array}$ & $\begin{array}{l}\text { gregoriana "Hodie } \\
\text { Christus natus est", do } \\
\text { "Magnificat" do Ofício } \\
\text { de Vésperas da festa de } \\
\text { Natal. }\end{array}$ & \\
\hline $\begin{array}{l}\text { Em Bethleem } \\
\text { (Coro e orquestra) }\end{array}$ & $\begin{array}{l}\text { Citação de materiais } \\
\text { geradores / Paráfrase } \\
\text { Na “Cantilena": o tema } \\
\text { inicial apresenta o } \\
\text { mesmo padrão } \\
\text { melódico da "Canção de } \\
\text { Solveig" de Grieg, a } \\
\text { saber, ascensão 5-1-(2)- } \\
3 \text { em modo menor } \\
\text { (caráter expressivo de } \\
\text { aceição da dor). } \\
\text { Entidades orgânicas } \\
\text { elementares (padrão de } \\
\text { acompanhamento) } \\
\text { Na “Cantilena": parte } \\
\text { orquestral com acordes } \\
\text { a modo de bordão nos } \\
\text { tempos fortes e acordes } \\
\text { completos nos tempos } \\
\text { fracos, regularidade, } \\
\text { função de } \\
\text { acompanhamento. } \\
\text { Procedimento idêntico à } \\
\text { “Canção de Solveig" de } \\
\text { Grieg. }\end{array}$ & $\begin{array}{l}\text { Paráfrase / Empréstimo } \\
\text { temático } \\
\text { Na “Cantilena”: } \\
\text { utilização da forma A- } \\
\text { A'-B-B' na estruturação } \\
\text { das frases vocais e } \\
\text { trecho constrastante } \\
\text { instrumental na } \\
\text { sequência: homônima } \\
\text { maior (Fá maior), } \\
\text { melodia de perfil } \\
\text { ascendente nos sopros } \\
\text { acompanhado por } \\
\text { alternância de acordes } \\
\text { subdominante-tônica. } \\
\text { Procedimento muito } \\
\text { semelhante à “Canção } \\
\text { de Solveig” de Grieg, } \\
\text { em que a parte vocal } \\
\text { segue o mesmo } \\
\text { esquema formal A-A'- } \\
\text { B-B' e em que também } \\
\text { há um trecho } \\
\text { contrastante na } \\
\text { sequência: ritmo } \\
\text { ternário, vocalize } \\
\text { acompanhado por } \\
\text { acordes dominante- } \\
\text { tônica na homônima } \\
\text { maior (Lá Maior) e } \\
\text { perfil melódico } \\
\text { ascendente. }\end{array}$ & 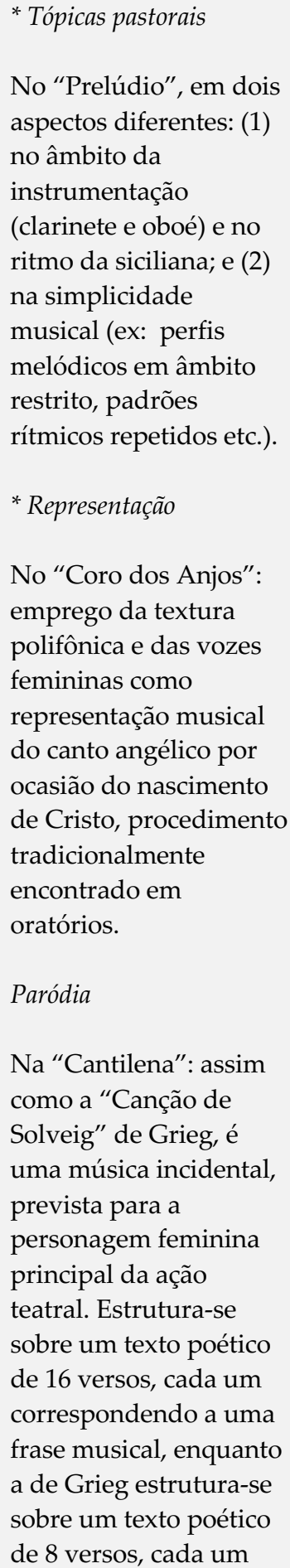 \\
\hline
\end{tabular}


MUSICA THEORICA Revista da Associação Brasileira de Teoria e Análise Musical 2020, v. 5, n. 1, p. 196-241 - Journal of the Brazilian Society for Music

Theory and Analysis @ TeMA 2020 - ISSN 2525-5541

\begin{tabular}{|c|c|c|c|}
\hline & & & $\begin{array}{l}\text { também } \\
\text { correspondendo a uma } \\
\text { frase musical. } \\
\text { Citação de esquemas } \\
\text { formais } \\
\text { Na "Cantilena": } \\
\text { estruturação formal } \\
\text { segundo o esquema } \\
\text { binário de canção, com } \\
\text { trecho instrumental } \\
\text { contrastante } \\
\text { (tonalidade, desenho } \\
\text { melódico, } \\
\text { instrumentação etc.) ao } \\
\text { final de cada seção. } \\
\text { Mesma forma "Canção } \\
\text { empregada na "Cadoig" de Grieg. } \\
\text { de Solveig }\end{array}$ \\
\hline $\begin{array}{l}\text { "Missa a duas vozes" } \\
\text { (Coro e órgão) }\end{array}$ & $\begin{array}{l}\text { Entidades orgânicas } \\
\text { elementares (padrão de } \\
\text { harmonização) } \\
\text { No primeiro “Kyrie } \\
\text { eleison”: harmonização } \\
\text { da melodia gregoriana } \\
\text { ao modo como alguns } \\
\text { tratadistas o entendiam } \\
\text { no final do século XIX } \\
\text { (utilização só de notas } \\
\text { da escala, acordes } \\
\text { correspondentes a cada } \\
\text { nota da melodia e } \\
\text { preferencialmente em } \\
\text { posição fundamental, } \\
\text { etc.) }\end{array}$ & $\begin{array}{l}\text { Citação textual- } \\
\text { empréstimo temático / } \\
\text { Paráfrase } \\
\text { (1) Tema introdutório } \\
\text { para solo de órgão com } \\
\text { perfil melódico e } \\
\text { função formal } \\
\text { semelhantes ao moteto } \\
\text { Ecce panis angelorum, de } \\
\text { L. Perosi. } \\
\text { (2) Trecho "Domine } \\
\text { Deus, agnus Dei, Filius } \\
\text { Patris" do "Gloria" } \\
\text { semelhante, em termos } \\
\text { de motivo melódico, de } \\
\text { harmonia, de texto e de } \\
\text { textura, ao mesmo } \\
\text { trecho da Missa Te } \\
\text { Deum laudamus de L. } \\
\text { Perosi. } \\
\text { (3) Toda a peça } \\
\text { "Sanctus" corresponde, } \\
\text { em termos formais e } \\
\text { temáticos, ao "Sanctus" } \\
\text { da Missa Te Deum } \\
\text { laudamus de L. Perosi. } \\
\text { Citação estilística com } \\
\text { intenção referencial. }\end{array}$ & $\begin{array}{l}\text { Citação de esquemas } \\
\text { formais. } \\
\text { (1) Utilização de um } \\
\text { tema introdutório para } \\
\text { solo de órgão como } \\
\text { elemento recorrente em } \\
\text { todas as peças da Missa } \\
\text { (prelúdio e interlúdio } \\
\text { do "Kyrie”; prelúdio e } \\
\text { interlúdio do "Gloria” } \\
\text { etc.), mesmo } \\
\text { procedimento utilizado } \\
\text { por L. Perosi em sua } \\
\text { Missa Te Deum } \\
\text { laudamus, de 1899. } \\
\text { (2) Utilização de } \\
\text { modelos formais } \\
\text { correspondentes, em } \\
\text { geral, à sistematização } \\
\text { proposta por G. Bas e, } \\
\text { em particular, à } \\
\text { utilizada por L. Perosi } \\
\text { na Missa Te Deum } \\
\text { laudamus: “Kyrie" com } \\
\text { tríplice divisão A-B-C; } \\
\text { "Gloria” com } \\
\text { quádrupla divisão (A- } \\
\text { B-C-A'); “Credo" com } \\
\text { quádrupla divisão (A- } \\
\text { B-C-Coda), cada parte } \\
\text { compreendendo } 5 \\
\text { versículos do texto; }\end{array}$ \\
\hline
\end{tabular}




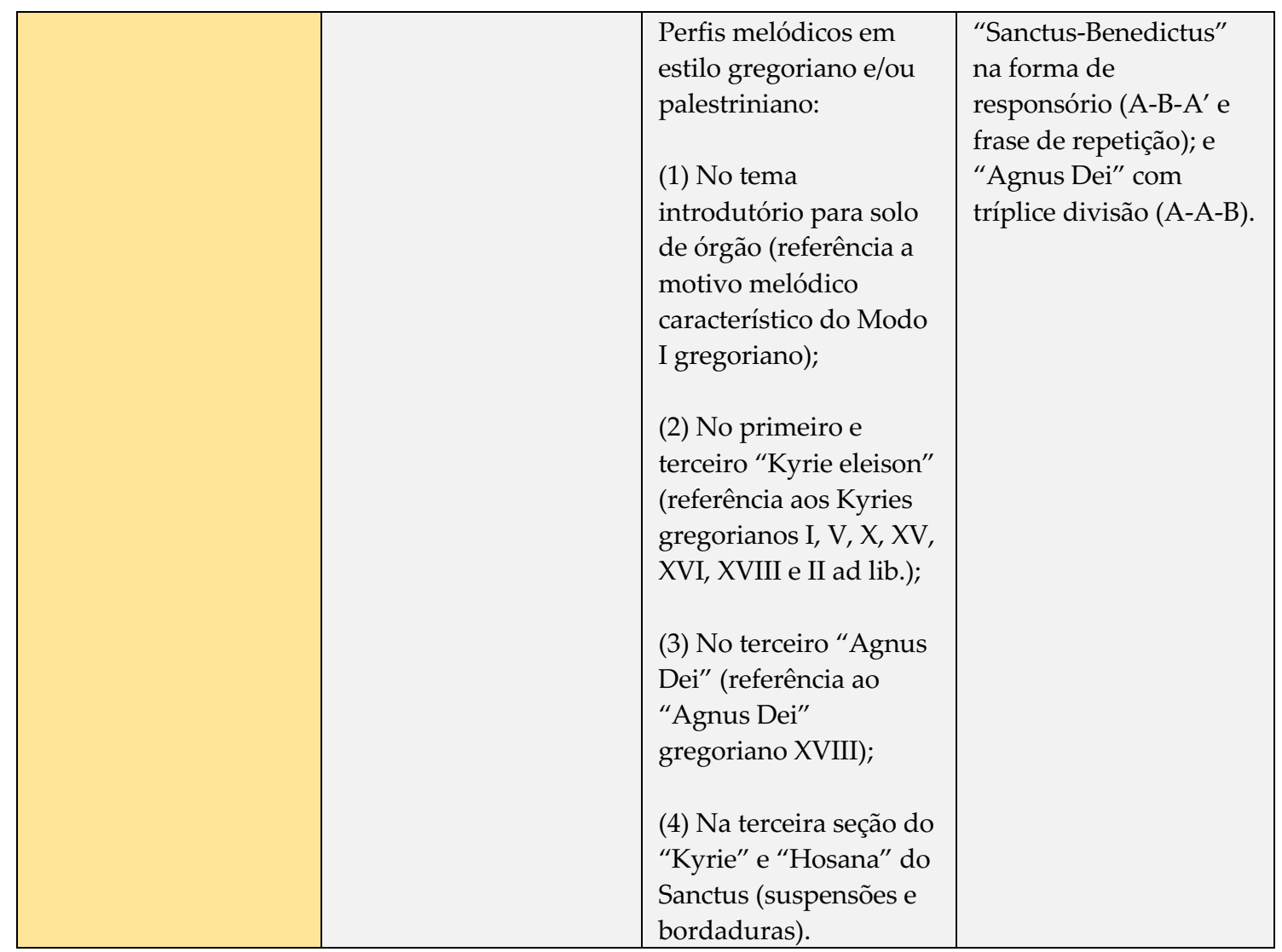

Tabela 3: Intertextualidade na obra religiosa de Alberto Nepomuceno; FONTE: O autor (2020)

\section{Referências}

1. Barbosa, Lucas de Paula e Barrenechea, Lúcia. 2003. A intertextualidade musical como fenômeno. Per Musi, v. 8, p. 125-136.

2. Barbosa, Lucas de Paula.; Barrenechea, Lúcia. 2005. A intertextualidade musical como fenômeno: um estudo sobe a influência da música de Chopin nas 12 Valsas de Esquina de Francisco Mignone. Em Pauta. Porto Alegre, v. 16, p. 37-72.

3. Bas, Julio. 1957. Tratado de la forma musical. Buenos Aires: Ricordi.

4. Burkholder, J. Peter. 2001. Intertextuality. In: The New Grove Dictionary of Music and Musicians. London: Macmillan.

5. Cooke, Deryck. 1973. The language of music. Oxford: Oxford University Press.

6. Corrado, Omar. 1992. Posibilidades intertextuales del dispositivo musical. In: Corrado, O; Kreichman, R.; Malachevsky, J. (Ed.). Migraciones de sentidos: tres 
enfoques sobre lo intertextual. Santa Fe: Universidad Nacional del Litoral, Centro de Publicaciones.

7. Ciampa, Leonardo 2006. Don Lorenzo Perosi. Bloomington: AuthorHouse.

8. Corrêa, Sergio N. A. 1996. Alberto Nepomuceno: Catálogo Geral. 2. ed.. Rio de Janeiro: Funarte.

9. Csampai, Attila; Holland, Dietmar. 1995. Guia básico dos concertos: música orquestral de 1700 até os nossos dias. Rio de Janeiro: Civilização Brasileira.

10. Dickensheets, Janice. 2012. The Topical Vocabulary of the Nineteenth Century. Journal of musicological research, v. 31, p. 97-137.

11. Green, Douglas M. 1979. Form in Tonal Music: An Introduction to Analysis. 2. ed. Fort Worth: Harcourt.

12. Grout, Donald. J.; Palisca, Claude V. 2007. História da Música Ocidental. 4. ed. Lisboa: Gradiva.

13. Kiefer, Bruno. 1976. História da música brasileira: dos primórdios ao início do séc. XX. Porto Alegre: Movimento.

14. Liber usualis. 1961. Tournai: Desclée \& Co.

15. López-Cano, Ruben. 2007. Música e intertextualidad. Pauta. Cuadernos de teoria y crítica musical. México, n. 104, p. 30-36.

16. Meyer, Leonard. 1996. Style and Music: Theory, History and Ideology. Chicago: University of Chicago Press.

17. Monelle, Raymond. 2006. Musical Topic: Hunt, Military and Pastoral. Bloomington: Indiana University Press.

18. Niedermeyer, Louis; D'ortigue, Joseph. 1905. Gregorian Accompaniment: A Theoretical and Practical Treatise upon the Accompaniment of Plainsong. London: Novello, Ewer \& Co.

19. Pereira, Avelino Romero. 2007. Música, sociedade e política: Alberto Nepomuceno e a República Musical. Rio de Janeiro: Editora UFRJ.

20. Ratner, Leonard. 1980. Classic Music: Expression, Form and Style. New York: Schirmer Book.

21. Schoenberg, Arnold. 2012. Fundamentos da composição musical. 3. ed. São Paulo: EdUSP.

22. Schubert, Guilherme. 1980. Música Sacra no Rio de Janeiro em redor de 1910. In: Brasil 1900-1910, p. 11-45. Rio de Janeiro: Biblioteca Nacional. 
23. Straus, Joseph N. 1990. Remaking the past: musical modernism and the influence of the tonal tradition. Cambridge: Harvard University Press.

24. Teixeira, Thiago Plaça; Dudeque, Norton. 2016. O Sanctus de Alberto Nepomuceno: um caso de intertextualidade musical. Musica Theorica. Salvador: TeMA, p. 18-46.

25. Vidal, João Vicente. 2011. Formação germânica de Alberto Nepomuceno: estudos sobre recepção e intertextualidade. 362 f. Tese (Doutorado em Música) Escola de Comunicações e Artes, Universidade de São Paulo, São Paulo.

26. Walker, Alan. 1997. Franz Liszt. Ithaca: Cornell University Press. v. 3: The final years, 1861-1886.

\section{Partituras}

27. Grieg, Edward. 1908. Solveig's Song. Boston: Oliver Ditson Co.

28. Liszt, Franz. [1872] Christus. Leipzig: Schuberth \& Co., s.d.

29. Liszt, Franz. 1916. Musikalische Werke. Serie II, Band 6 [Annés de Pèlerinage, Troisième Année]. p. 148-195. Leipzig: Breitkopf \& Härtel.

30. Liszt, Franz. 1927. Musikalische Werke. Serie II, Band 9 [Weihnachtsbaum]. p. 111158. Leipzig: Breitkopf \& Härtel.

31. Liszt, Franz. 1978a. Neue Liszt-Ausgabe. Serie 1, Band 12 [Stabat Mater]. p. 2834. Budapest: Editio Musica/Kassel: Bärenreiter.

32. Nepomuceno, Alberto. 1926. Álbum Eucarístico. Rio de Janeiro: Sampaio Araújo \& Cia.

33. Nepomuceno, Alberto. [1915a] Cloches de Noël. Rio de Janeiro: Sampaio Araújo \& Cia.

34. Nepomuceno, Alberto. [1903] Em Bethleem. Fundação Biblioteca Nacional Divisão de Música e Arquivo Sonoro, M785.1. Partitura manuscrita.

35. Nepomuceno, Alberto. 1915b. Missa: duabus vocibus aequalibus quam in honorem Virginis Immaculatae concinnavit et eminentíssimo Domino Cardinali Arcoverde dicavit. Rio de Janeiro: E. Bevilacqua.

36. Perosi, Lorenzo. [1899a] Il Natale del Redentore. Milano: G. Ricordi \& C.

37. Perosi, Lorenzo. 1900. Melodie sacre. Milan: Musica Sacra Bertarelli, s.d. [1900]. v. 4. Partitura (49 p.). Coro e órgão. 
MUSICA THEORICA Revista da Associação Brasileira de Teoria e Análise Musical 2020,

v. 5, n. 1, p. 196-241 - Journal of the Brazilian Society for Music

38. Perosi, Lorenzo. 1899b. Missa "Te Deum laudamus" ad duas voces facillima comitente Organo. Milão: Ricordi.

39. Saint-Saëns, Camille. [1891] Oratorio de Noël, Op. 12. New York: G. Schirmer.

\section{Periódicos}

40. A União, Rio de Janeiro, 18/09/1905.

41. A União, Rio de Janeiro. 21/10/1920.

42. Gazeta de Notícias, Rio de Janeiro, 27/06/1898.

43. Gazeta de Notícias, Rio de Janeiro, 02/07/1898.

44. Gazeta de Notícias, Rio de Janeiro, 07/07/1898.

45. O Imparcial, Rio de Janeiro, 27/07/1917.

46. Jornal do Commercio, Rio de Janeiro, 17/07/1917. 